\title{
Geo-thermochronology of the Saint Antonin basin, south-eastern France
}

\author{
Sébastien Jourdan ${ }^{1}$, Matthias Bernet ${ }^{1, *}$, Elizabeth Hardwick ${ }^{1}$, Jean-Louis Paquette ${ }^{2}$, Pierre Tricart $^{1}$, \\ François Senebier ${ }^{1}$ and Francis Coeur ${ }^{1}$ \\ ${ }^{1}$ Institut des Sciences de la Terre, Université Grenoble Alpes, CNRS, 1381 Rue de la piscine, 38041 Grenoble cedex, France \\ ${ }^{2}$ Laboratoire Magmas et Volcans, UMR6524 CNRS \& Université Blaise Pascal, 5 Rue Kessler, 63038 Clermont-Ferrand, \\ France
}

Received: 16 January 2018 / Accepted: 22 July 2018

\begin{abstract}
The clastic sedimentary formations of the Saint Antonin basin in the French Maritime Alps contain the record of the Early Oligocene erosional history of the Maures-Esterel massif, Sardinia and Corsica. Detrital apatite fission-track dating and zircon fission-track/U-Pb double dating of samples collected from the Saint Antonin basin confirm sediment provenance and allow obtaining first-order estimates of drainage basin maximum and long-term average exhumation rates. Whereas average exhumation rates were on the order of $0.1-0.2 \mathrm{~km} / \mathrm{Myr}$ during the Early Oligocene, small parts of the Saint Antonin basin source areas may have experienced maximum exhumation rates on the order of $0.4-0.7 \mathrm{~km} / \mathrm{Myr}$. Although zircons and apatites with Early Oligocene fission-track cooling ages make up between $11-15 \%$ of the dated grains, a possible volcanic contribution is negligible, as only one single volcanic zircon grain was identified by fission-track/U-Pb double dating. Regional geodynamic processes with convergence in the Western Alps to the east and the end of the Pyreneo-Provençal compression phase by the early Oligocene controlled the differences in basin fill history and sediment provenance between the Saint Antonin basin and the largely contemporaneous Barrême basin in southeastern France.
\end{abstract}

Keywords: Saint Antonin basin / geo-thermochronology / provenance / exhumation / tectonics

Résumé - Géo-thermochronologie du bassin de Saint Antonin, sud-est de la France. Les formations sédimentaires clastiques du bassin de Saint Antonin, dans les Alpes Maritimes françaises, contiennent les archives de l'histoire oligocène précoce de l'érosion du massif des Maures-Esterel, de la Sardaigne et de la Corse. La datation par traces de fission sur apatites détritiques et la double datation trace de fission/U-Pb sur les mêmes grains de zircon des échantillons recueillis dans le bassin de Saint Antonin confirment la provenance des sédiments et permettent d'obtenir des estimations de premier ordre des taux d'exhumation maximaux et moyens à long terme. Alors que les taux d'exhumation moyens étaient de l'ordre de 0,1 à $0,2 \mathrm{~km} / \mathrm{Myr}$ au début de l'Oligocène, de petites parties des zones sources du bassin de Saint Antonin ont pu connaître des taux d'exhumation maximum de l'ordre de 0,4 à $0,7 \mathrm{~km} / \mathrm{Myr}$. Bien que les zircons et les apatites avec des âges de refroidissement de traces de fission oligocène précoce représentent entre 11 et $15 \%$ des grains datés, une contribution volcanique possible est négligeable, car un seul grain de zircon volcanique a été identifié par double datation trace de fission/U-Pb. Les processus géodynamiques régionaux avec convergence dans les Alpes occidentales à l'est et la fin de la phase de compression pyrénéo-provençale au début de l'oligocène contrôlent les différences d'histoire de remplissage du bassin et de provenance des sédiments entre le bassin de Saint Antonin et le bassin de Barrême, largement contemporain dans le sud-est de la France.

Mots clés : bassin de Saint Antonin / géo-thermochronologie / provenance / exhumation / tectonique

\footnotetext{
*Corresponding author: matthias.bernet@univ-grenoble-alpes.fr
} 


\section{Introduction}

The Haute Provence-Maritime Alps region in southeastern France is characterized by a complex geodynamic evolution. North-south directed deformation during the Eocene-early Oligocene was driven by the Pyreneo-Provençal compression phase, which had started during the Late Cretaceous, followed by late Oligocene-early Miocene opening of the Ligurian Sea (Jolivet et al., 1990, 1991; Rosenbaum et al., 2002; Lacombe and Jolivet, 2005). Eastwest directed compressional deformation initiating during the early Oligocene was related to Alpine convergence between the Apulian and European plates (e.g., Lacombe and Jolivet, 2005; Dumont et al., 2012 and references therein). The intersection of the two N-S and E-W deformation patterns is well preserved in the Arc de Castellane (Fig. 1a). Eoceneearly Oligocene deposits derived from the Corsica-Sardinia block are preserved in the Saint Antonin basin, which experienced synsedimentary deformation during the final stages of the Pyreneo-Provençal N-S shortening phase (Campredon and Giannerini, 1982). Eocene to late Oligocene/early Miocene sediments of the Alpine foreland basin are preserved in basin remnants of the Barrême and Annot basins, among others. These basins show east-west shortening (Fig. 1b and c). The Saint Antonin, Barrême and Annot basin remnants have received attention over the past 100 years, which is reflected in a series of publications, culminating in a special publication by Joseph and Lomas (2004 and references therein) on the Grès d'Annot turbidite systems and their equivalence in the Barrême and Saint Antonin basins.

Reconstructions of sediment provenance and potential source areas in these basins are important for understanding source-to-sink relationships and the evolution of the Western Alps foreland basin in general. Provenance studies based on heavy mineral analysis and sediment petrology in the Barrême, Annot and Saint Antonin basins (e.g., Stanley, 1964; Bodelle, 1971; Evans and Mange-Rajetzky, 1991; Evans et al., 2004) provided important information on sediment source areas and routing systems. These studies showed that during the Eoceneearly Oligocene sediments were delivered to these three basins from the Maures-Esterel massif and the Corsica-Sardinia block located to the south. A change of sediment provenance between about 30-29 Ma has been reported for the Barrême basin in terms of sediment petrology, paleocurrent transport directions and zircon fission-track and $\mathrm{U}-\mathrm{Pb}$ data (e.g., Evans and Mange-Rajetzky, 1991; Evans et al., 2004; Jourdan et al., 2013), but not for the Saint Antonin or the Annot basin, because the Saint Antonin basin never received sediments from the Western Alps, and deposition in the Annot basin had ended by that time.

Detrital apatite fission-track (AFT) and zircon fission-track (ZFT) and $\mathrm{U}-\mathrm{Pb}$ single grain double dating can provide additional information on sediment provenance, as well as the exhumation history of sediment source areas (e.g., Zeitler et al., 1986; Cerveny et al., 1988; Carter, 1999; Carter and Moss, 1999; Garver et al., 1999; Bernet and Garver, 2005; Bernet et al., 2006; Jourdan et al., 2013). The purpose of this study is combine sediment provenance information with rates of source area exhumation. Therefore, we present geothermochronological data from six samples of detrital apatite and zircon collected from the three main sedimentary units of the latest Eocene to early Oligocene sedimentary sequence preserved in the Saint Antonin basin syncline (Tab. 1). Similar data have already been published for the Barrême and Annot basins (Bernet et al., 2009; Jourdan et al., 2013), which allows for a good comparison of the thermochronological signal in the different foreland basin remnants. The times of deposition of the sedimentary sequences in the Saint Antonin basin have previously been constrained by biostratigraphy (Callec, 2001). We use the minimum age approach for comparing the youngest age population of each sample with the biostratigraphically constrained depositional ages of the three formations for estimating maximum source area exhumation rates. Central ages of the AFT and ZFT grain-age distributions of our samples are used for first-order estimates of average long-term exhumation rates of the paleo-drainage areas. Zircon $\mathrm{U}-\mathrm{Pb}$ ages of grains already dated with the fission-track method were determined in order to identify a possible Paleogene volcanic contribution, which may perturb the exhumation signal, as it was done in a previous Barrême basin study (Jourdan et al., 2013).

\section{Geological setting}

\subsection{The Saint Antonin basin}

The Saint Antonin basin is located in the French Maritime Alps, within the Castellane arc, $30 \mathrm{~km}$ northwest of Nice (Fig. 1a). The east-west striking basin is about $4.5 \mathrm{~km}$ wide and $20 \mathrm{~km}$ long and more than $1000 \mathrm{~m}$ of detrital sediments accumulated in this basin during the late Eocene to early Oligocene (e.g., Bodelle, 1971; Stanley, 1980 and references therein; Callec, 2001). The Saint Antonin basin is a structurally complex syncline with three minor sub-basins, formed between two anticlines (Fig. 1b and c; Campredon and Giannerini, 1982).

Typical for the Tertiary basin deposits in the Alpine realm, the stratigraphy of the Saint Antonin basin represents the classic trinity of Nummulitic limestone, Blue (or Globigerina) marls, and relatively coarse grained clastic sedimentary deposits (Fig. 2). The borders of the Saint Antonin basin syncline are outlined by outcrops of Nummulitic limestone (Fig. 1b). The coarse clastic deposits have been subdivided into three units called the lower, middle and upper member of the Saint Antonin conglomerate by Stanley (1980), or simply Formations 1, 2 and 3 by Bodelle (1971) and Callec (2001); we use the latter nomenclature here (Fig. 2). A series of different depositional environments have been proposed for the three formations, ranging from alluvial/lacustrine, fluvial- to tidedominated shallow marine and deep marine sediments (e.g., Stanley, 1980 and references therein; Callec, 2001). Following Callec (2001), the sampled units were deposited between 33 and $28 \mathrm{Ma}$.

In general, the three formations are composed of poorly sorted coarse conglomerates, fine to medium grained sandstones and silt, and locally in the upper part, also of andesitic breccias (Fig. 2). Formation 1, which is about $200-400 \mathrm{~m}$ thick, begins with medium to coarse grained, well-sorted sandstones that contain sedimentary structures including ripple marks, mud drapes and flaser bedding, typical of a tidal 

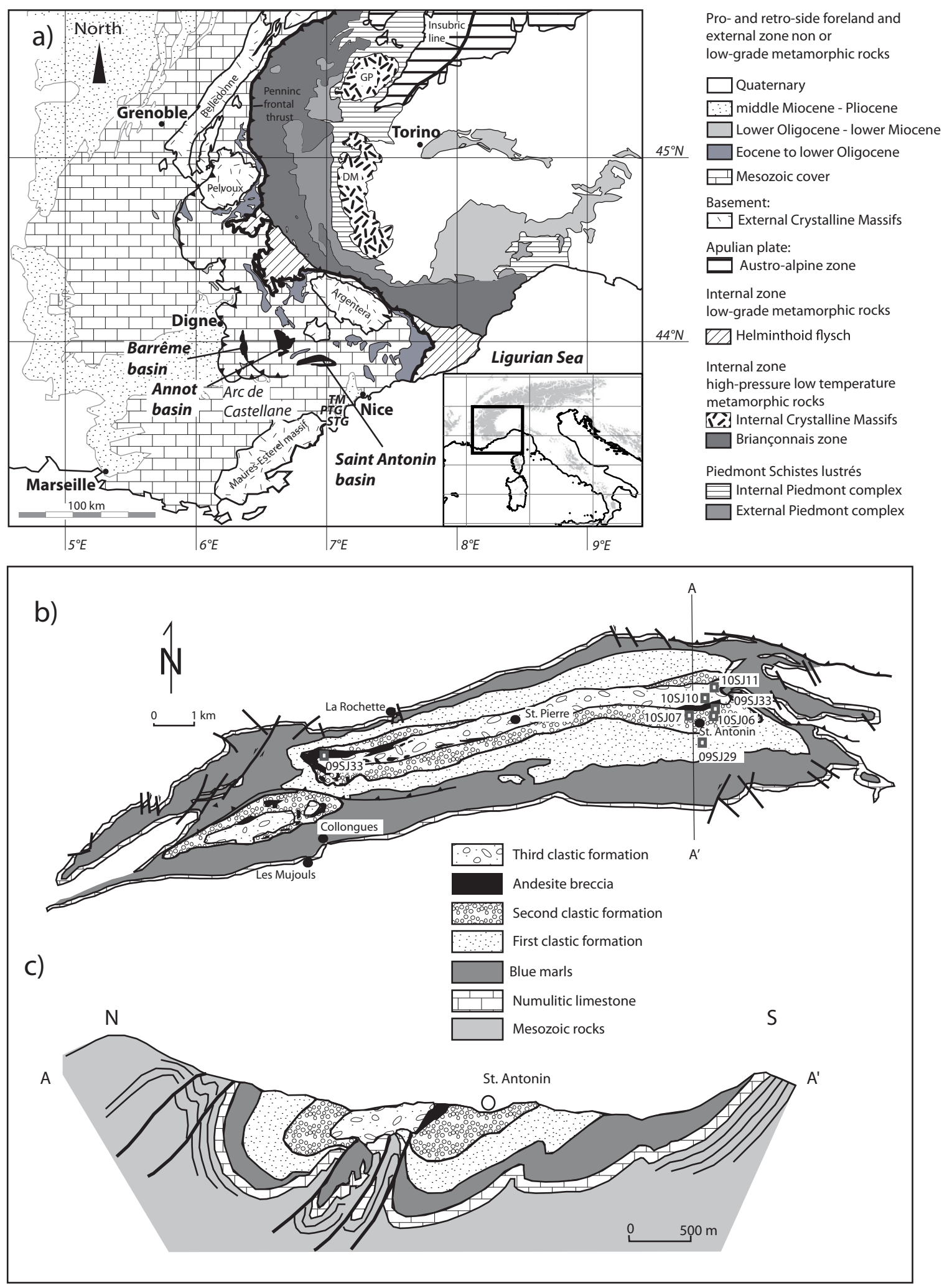

Fig. 1. a) Regional overview map of southeastern France showing the location of the Saint Antonin basin, Annot basin, and Barrême basin. TM: Tanneron massif; PTG: Plan de la Tour granite; STG: Saint Tropez granite. b) Simplified geologic map. c) Cross-section of the Saint Antonin basin modified after Campredon and Giannerini (1982). 
Table 1. Sample locations.

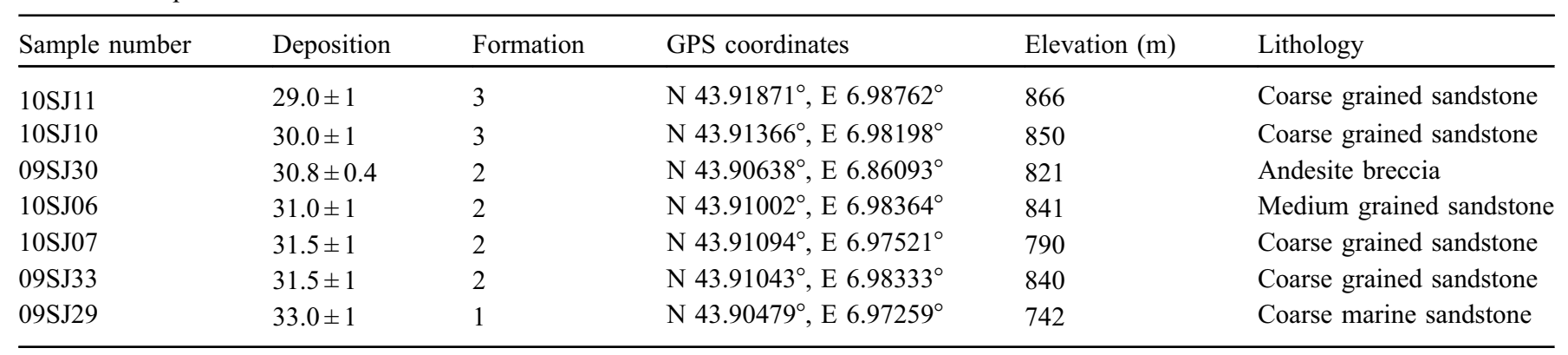

\section{Saint Antonin Stratigraphy}

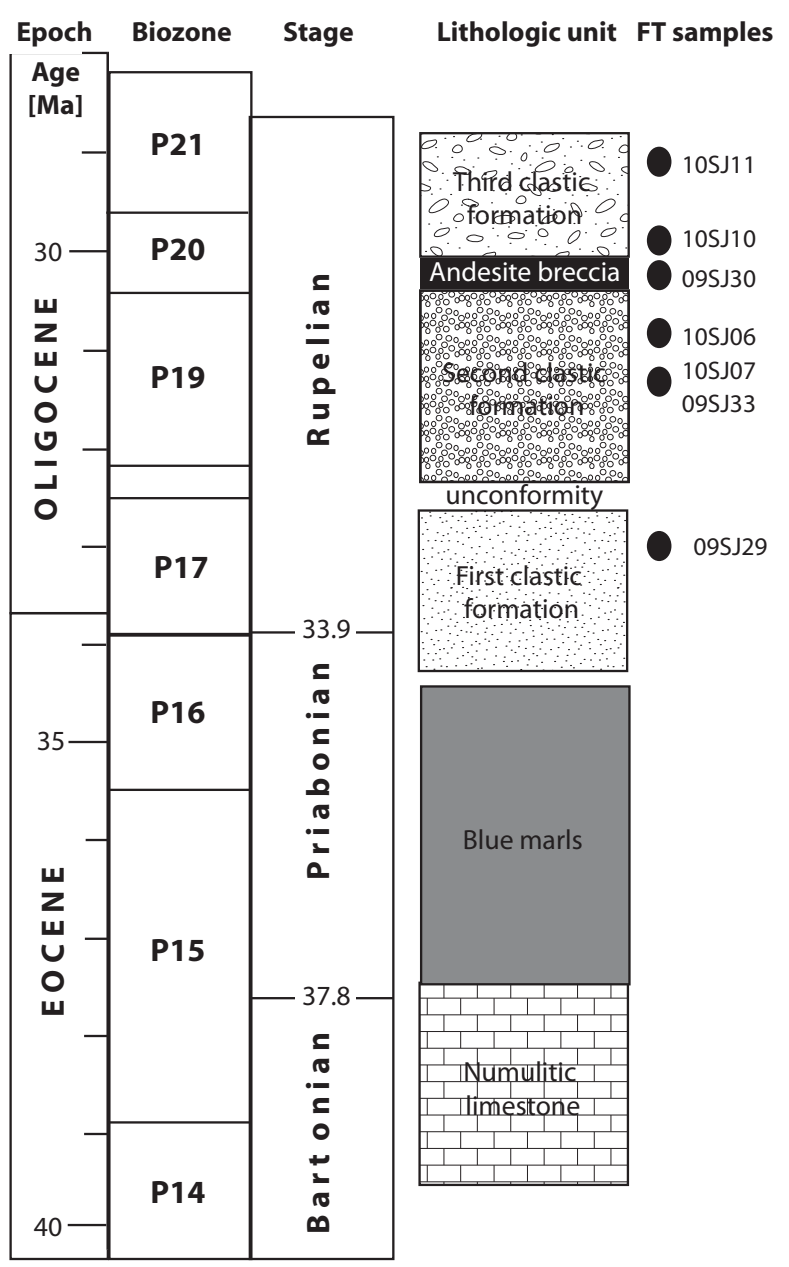

\section{Barreme basin Stratigraphy}

\begin{tabular}{l} 
Grès Verts \\
\hline Série Grise \\
\hline Série Saumon \\
\hline
\end{tabular}

Molasse Rouge

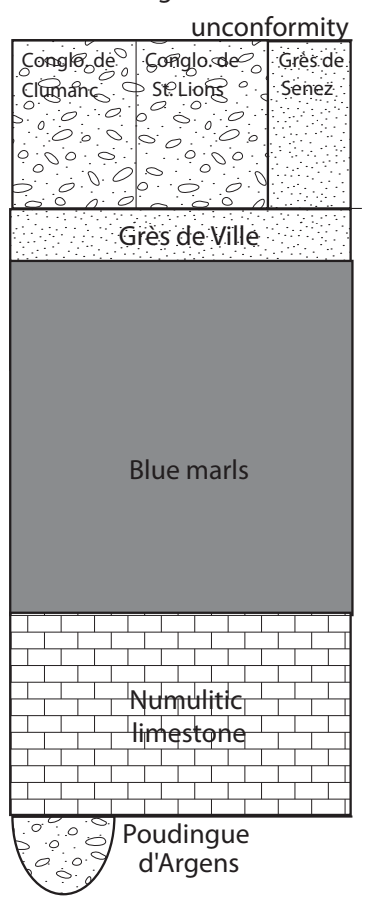

Fig. 2. Simplified stratigraphic columns of the Saint Antonin basin, showing stratigraphic position of the samples in the log (modified after Bodelle, 1971; Stanley, 1980; Callec, 2001), and the Barrême basin (modified after Jourdan et al., 2013). 
flat depositional environment. Formation 1 shows a coarsening upward trend into conglomeratic layers. In the southeastern part of the basin decametric to metric granite blocks have been described in the literature (Toure, 1981). The $220-350 \mathrm{~m}$ thick Formation 2 represents another sandy-conglomeratic coarsening upward sequence, which is characterized by the occurrence of andesite breccias and conglomeratic lenses (Bodelle, 1971; Stanley, 1980). Andesite pebbles at the base and the top of Formation 2 have been dated with the ${ }^{40} \mathrm{Ar} /{ }^{39} \mathrm{Ar}$ dating method to $31.1 \pm 0.4 \mathrm{Ma}$ and $30.8 \pm 0.4 \mathrm{Ma}$, respectively (Montenat et al., 1999). Formation 3 is the third coarsening upward unit composed of sand and conglomerates, but with a lower proportion of andesitic breccias and pebbles than in Formation 2. Formation 3 is between $180-500 \mathrm{~m}$ thick and shows continental characteristics including fluvial channel and overbank deposits particularly in its upper part in the south-eastern corner of the Saint Antonin basin (Campredon and Giannerini, 1982; Callec, 2001).

The Saint Antonin basin area experienced a first phase of deformation during the Late-Middle Paleogene, which is reflected by shortening of the underlying Nummulitic limestones and the unconformity with the overlying clastic sedimentary rocks. Late Paleogene syn-sedimentary northsouth directed tectonic shortening caused uplift of the southern flank of the Saint Antonin basin syncline and exposure above sea level accompanied by fluvial sedimentation during deposition of Formation 3. A third regional northwest-southeast directed shortening phase affected the Saint Antonin basin area during the Miocene (Beaudoin et al., 1977; Campredon and Giannerini, 1982; Schreiber et al., 2010).

\subsection{Sediment provenance of the Saint Antonin basin clastic formations}

In the field, the first indication of sediment provenance is the pebble lithology present in the conglomeratic layers of the three formations. In Formation 1, granite, gneiss, sandstone, limestone, rhyolite and basalt pebbles can be observed. For most of the pebbles, the origin is unknown, but the limestone and red rhyolite pebbles in the Saint Antonin conglomerates may have been derived from the sedimentary cover of the Maures-Esterel massif (Bodelle, 1971). Furthermore, it has been proposed by Bodelle (1971) that large, metric-scale boulders of fine grained porphyritic monzogranite, particularly abundant in Formation 1, were derived from a local source to the south of the basin, which has been completely eroded, as no equivalent monzogranites are known in the Corsica-Sardinia block or the Maures-Esterel massif (Toure, 1981).

In Formation 2, Bodelle (1971) identified gabbro with characteristics typical of gabbros found in Alpine Corsica, whereas in Formation 3, Bodelle (1971) identified syenite pebbles that correspond to syenite from outcrops in Hercynian Corsica. These observations of southern sources in the MauresEsterel massif and the Corsica-Sardinia block are consistent with paleocurrent data (Bodelle, 1971; Stanley, 1980; Callec, 2001) and paleogeographic reconstructions as presented in Joseph and Lomas (2004).

\subsection{The Maures-Esterel massif and the Corsica- Sardinia block}

The crystalline rocks of the Maures-Esterel massif consist mostly of Proterozoic to Paleozoic quartzite, mica schist, gneiss and migmatite, but also of Carboniferous granite and Permian rhyolites. The intrusions, volcanic activity, and part of the metamorphism in the Maures-Esterel massif are associated with the Hercynian orogeny, which also affected part of the crystalline basement of Corsica and Sardinia. The bedrock geology of Corsica is divided into two parts. With the exception of a few outcrops of pre-Hercynian basement rocks, the so-called Hercynian Corsica consists of the Carboniferous Corsica batholith, Permian intrusive and volcanic rocks, and Mesozoic-Cenozoic cover units (e.g., Zarki-Jakni et al., 2004; Danisik et al., 2007; Malusà et al., 2016 and references therein). The second and younger part is Alpine Corsica, consisting of an Alpine metamorphic core complex (e.g., Jolivet et al., 1990; Fournier et al., 1991). During the Jurassic, Corsica and Sardina were tectonically juxtaposed, and during the Cretaceous and Eocene the Maures-Esterel massif, Tanneron massif, Corsica, and Sardinia supposedly formed one block in the Pyreneo-Provençal relief (Malavieille et al., 1998; Andreani et al., 2010, Malusà et al., 2015). Between 33 and $22 \mathrm{Ma}$ Corsica and Sardinia separated from the French Maritime Alps and the Maures-Esterel massif during rifting and opening of the Ligurian Sea (Séranne, 1999; Brunet et al., 2000; Lacombe and Jolivet, 2005; Zarki-Jakni et al., 2004). This rifting started in the western Gulf of Lion (Jolivet et al., 2015).

\section{Methods}

\subsection{Fission-track analysis}

Seven samples were collected in the field, six from sandstone layers and one from an andesite breccia of Formation 2 (Tab. 1, Fig. 2). Apatite and zircon crystals were separated from bulk rock sandstone samples after crushing and sieving (80-160 $\mu \mathrm{m}$ fraction), using standard magnetic and heavy liquid separation techniques. The andesite breccia sample yielded neither apatite nor zircon. Apatite aliquots from the sandstone samples were mounted in an epoxy resin, polished and etched for $20 \mathrm{~s}$ at $21^{\circ} \mathrm{C}$ in $5.5 \mathrm{M} \mathrm{HNO}_{3}$. The samples, covered with muscovite sheets as external detectors, were irradiated together with Durango and Fish Canyon Tuff age standards and IRMM540R dosimeter glasses at the FRM II Research Reactor in Garching, Germany.

Zircon aliquots were mounted in Teflon sheets, polished and etched in a laboratory oven at $228^{\circ} \mathrm{C}$ between 10 and $35 \mathrm{~h}$ in a eutectic melt of $\mathrm{NaOH}$ and $\mathrm{KOH}$. The zircon samples, also covered with white mica detectors, were irradiated together with Buluk and Fish Canyon Tuff age standards and CN1 dosimeter glasses. After irradiation, all mica detectors were etched at $21^{\circ} \mathrm{C}$ for $18 \mathrm{~min}$ in $48 \%$ hydrofluoric acid.

All fission-track analyses were done in the ISTerre fissiontrack laboratory in Grenoble, France. Fission-tracks were counted dry at $1250 \times$ magnification in grains mounted parallel to their C-axis, using an Olympus BX51 microscope and the FTStage 4.04 system of T. Dumitru. The grain age distributions of all samples are presented in radial plots, and minimum and 
Table 2. Apatite fission-track data.

\begin{tabular}{|c|c|c|c|c|c|c|c|c|c|c|c|c|c|}
\hline $\begin{array}{l}\text { Sample } \\
\text { number }\end{array}$ & $\begin{array}{l}\text { Deposition } \\
(\mathrm{Ma})\end{array}$ & $n$ & $\begin{array}{l}\text { Age range } \\
(\mathrm{Ma})\end{array}$ & $\begin{array}{l}\rho_{\mathrm{s}} \\
\left(10^{-5} \mathrm{~cm}^{-2}\right)\end{array}$ & $\mathrm{N}_{\mathrm{s}}$ & $\begin{array}{l}\rho_{\mathrm{i}} \\
\left(10^{-5} \mathrm{~cm}^{-2}\right)\end{array}$ & $\mathrm{N}_{\mathrm{i}}$ & $\begin{array}{l}\rho_{\mathrm{d}} \\
\left(10^{-5} \mathrm{~cm}^{-2}\right)\end{array}$ & $P\left(\chi^{2}\right)$ & $\begin{array}{l}\text { Central } \\
\text { Age (Ma) }\end{array}$ & $\pm 1 \sigma$ & $\begin{array}{l}\text { Minimum } \\
\text { age }(\mathrm{Ma})\end{array}$ & $\pm 1 \sigma$ \\
\hline 10SJ11 & $29.0 \pm 1$ & 52 & $31.1-458.2$ & 11.2 & 2050 & 11.6 & 2116 & 7.24 & 0 & 83.1 & 6.4 & 44.3 & 7.4 \\
\hline 10SJ07 & $31.5 \pm 1$ & 90 & $25.0-328.5$ & 14.2 & 3381 & 13.7 & 3258 & 7.25 & 0 & 85.5 & 4.7 & 46.1 & 4.7 \\
\hline
\end{tabular}

Note: Samples were counted dry with a BX51 Olympus microscope at $1250 \times$ magnification. Central and minimum ages were calculated with the RadialPlotter program of Vermeesch (2009), using a zeta value of $214.63 \pm 18.5$ and the IRMM540R dosimeter glass. $\rho$ s: spontaneous track density; $\rho$ i: induced track density; $\rho d$ : track density of the fluence monitor.

central ages (Galbraith and Laslett, 1993) were calculated with the RadialPlotter program of Vermeesch (2009). Given the relatively close age of deposition of about $31 \pm 2 \mathrm{Ma}$ of the sampled units, we combined all AFT and ZFT single grain age data for binomial peak fitting using BINOMFIT of Brandon (see Stewart and Brandon, 2004; Ehlers et al., 2005) to determine the main grain age components for provenance analysis (e.g., Bernet et al., 2004; Bernet and Garver, 2005).

The first-order drainage basin maximum and average exhumation rates are estimated from the 1-D thermal advection model age2edot by Brandon (see Ehlers et al., 2005 for details), using the lag-time concept (e.g., Garver et al., 1999; Bernet and Garver, 2005). In this study, lag times are calculated:

- for the maximum exhumation rate estimates by subtracting the depositional age from the minimum age, and;

- for the average exhumation rate estimates by subtracting the depositional age from the central age of each sample.

\subsection{Zircon $\mathrm{U}-\mathrm{Pb}$ dating and single grain fission-track/ $\mathrm{U}-\mathrm{Pb}$ double dating}

A selection of zircons mounted in Teflon ${ }^{\circledR}$ sheets for fissiontrack analysis were dated with the laser-ablation ICP-MS U-Pb dating method at the Laboratoire Magmas et Volcans, Blaise Pascal University, Clermont-Ferrand, France. An Agilent 7500 ICP mass spectrometer coupled to a fully computer-controlled $193 \mathrm{~nm}$ Resonetics M-50E excimer laser were used with a $20 \mu \mathrm{m}$ diameter spot size (Hurai et al., 2010 and 2012). Some of the same grains had been dated first with the fission-track method for double-dating of single grains. The objective was to analyse the core of the grains to determine if they have 30-38 Ma or much older $(>>100 \mathrm{Ma})$ crystallization ages, in order to identify a possible Paleogene volcanic contribution. Certain zircon crystals experienced lead-loss, but this is of limited relevance in this study, as no high precision ages are needed to distinguish between Eocene-Oligocene and Hercynian, Pan African or older crystallization ages. All U-Pb data and Concordia plots can be consulted in the supplementary data files.

\section{Results}

\subsection{Fission-track results}

AFT ages were determined for samples 10SJ06 and 10SJ07 collected from Formation 2, and sample 10SJ11 collected from Formation 3. The AFT data are shown in Table 2 and presented in radial plots in Figure 3. All these samples show similar results with minimum ages between about 37 and $48 \mathrm{Ma}$ and central ages between 73 and $86 \mathrm{Ma}$. The spontaneous versus induced track-density plot shows a wide range of values, which is common for the analysis of detrital grains that were not reset after deposition (Fig. 4a), and the uranium concentration versus AFT cooling age plot (Fig. 4b) shows that the majority of grains have uranium concentrations between 10 and $40 \mathrm{ppm}$ but with extreme values of $<5 \mathrm{ppm}$ and $>120 \mathrm{ppm}$.

The ZFT data are shown in Table 3 and in radial plots in Figure 5. The ZFT minimum ages between 33 and $49 \mathrm{Ma}$ and central ages between 74 and $85 \mathrm{Ma}$ are very similar to the AFT results. Similar to the apatite grains, the spontaneous versus induced track-density plot (Fig. 6a) shows a wide range of values, as it would expected from zircons of detrital samples. The uranium concentration versus ZFT cooling age plot (Fig. 6b) shows that most analysed grains have uranium concentration between 100 and 400 ppm.

Lag-times calculated from AFT and ZFT minimum and central ages are given in Table 4. AFT lag times vary between 6.6 and 15.3 Myr, with a mean around $12.2 \pm 4.3 \mathrm{Myr}$ for minimum ages, and between 42.8 and $54.1 \mathrm{Myr}$, with a mean of $50.3 \pm 4.3 \mathrm{Myr}$ for central ages. ZFT lag times range from 4.4 to $19.0 \mathrm{Myr}$, with a mean around $12.3 \pm 4.8 \mathrm{Myr}$ for minimum ages, and from 41.0 to $54.4 \mathrm{Myr}$, with a mean of $46.3 \pm 5.6 \mathrm{Myr}$ for central ages.

Binomial peak fitting results of the AFT and ZFT data are shown in Figure 7 (also see the data repository for single grain data). Given the close range of depositional ages of sampled units to obtain a general detrital age signal of the Saint Antonin basin the grain ages can be combined and treated as one sample. The combined 244 single grain AFT ages of the three samples can be decomposed into four major age components at about 37, 59, 85, and $175 \mathrm{Ma}$. The best-fit solution for the combined 206 single grain ZFT ages of the four samples results in three major age peaks at about 33,61, and $134 \mathrm{Ma}$.

\subsection{Zircon $\mathrm{U}-\mathrm{Pb}$ and fission-track/U-Pb double dating results}

A total of 109 zircons were dated with LA-ICP-MS analysis (Fig. 8a) and 62 of these zircons were previously dated with the fission-track method (Fig. 8b). With the exception of one single zircon from sample 10SJ10 in Formation 3, with a crystallization age of $30 \pm 1 \mathrm{Ma}$, all other zircons have $\mathrm{U}-\mathrm{Pb}$ ages ranging between $277-2812 \mathrm{Ma}$ (Fig. 8a). Almost $40 \%$ of 
10SJ06 $(n=102)$

Central age $=73.8 \pm 4.1 \mathrm{Ma}(1 \sigma)$

Dispersion $=50 \%$

$P\left(x^{2}\right)=0.00$

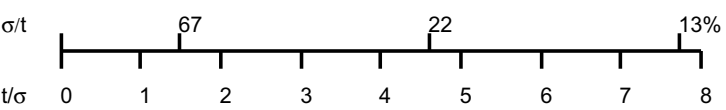

10SJ07 (n=90)

Central age $=85.5 \pm 4.7 \mathrm{Ma}(1 \sigma)$

Dispersion $=46 \%$

$P\left(\chi^{2}\right)=0.00$
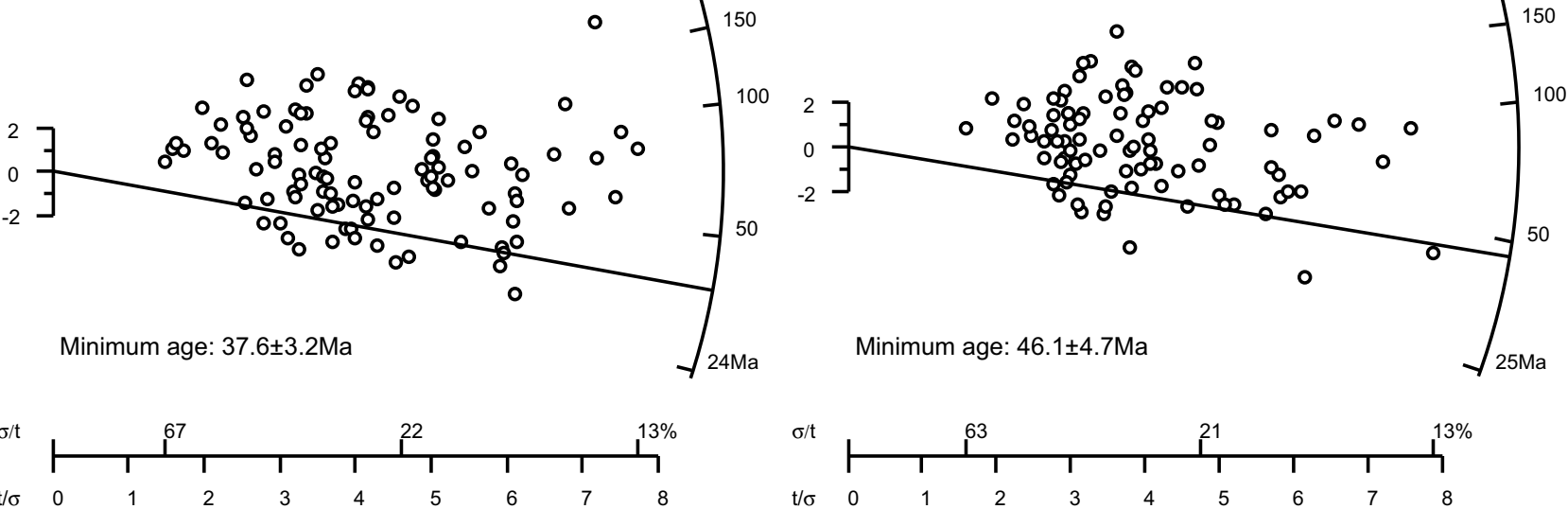

10SJ11 ( $\mathrm{n}=52)$

Central age $=83.1 \pm 6.4 \mathrm{Ma}(1 \sigma)$

Dispersion $=50 \%$

$\mathrm{P}\left(\alpha^{2}\right)=0.00$
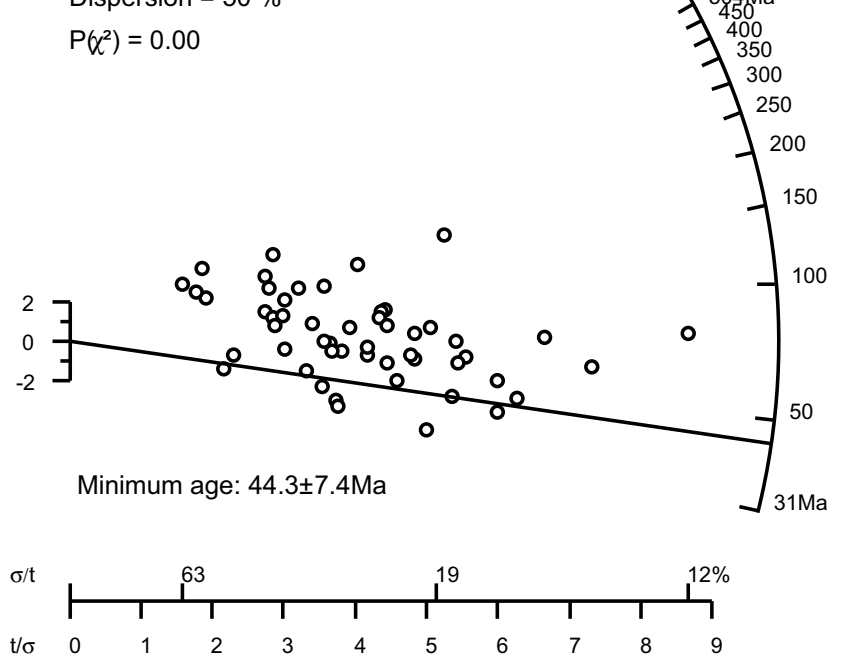

Fig. 3. Detrital AFT age data shown in radial plots for samples 10 SJ06 and 10SJ07 of Formation 2, and sample 10SJ11 of Formation 3. Graphs were plotted and central and minimum ages were calculated with the RadialPlotter program by Vermeesch (2009).

Table 3. Zircon fission-track data

\begin{tabular}{|c|c|c|c|c|c|c|c|c|c|c|c|c|c|}
\hline $\begin{array}{l}\text { Sample } \\
\text { number }\end{array}$ & $\begin{array}{l}\text { Deposition } \\
\text { (Ma) }\end{array}$ & $n$ & $\begin{array}{l}\text { Age } \\
\text { range } \\
(\mathrm{Ma})\end{array}$ & $\begin{array}{l}\rho_{\mathrm{s}} \\
\left(10^{-5} \mathrm{~cm}^{-2}\right)\end{array}$ & $\mathrm{N}_{\mathrm{s}}$ & $\begin{array}{l}\rho_{\mathrm{i}} \\
\left(10^{-5} \mathrm{~cm}^{-2}\right)\end{array}$ & $\mathrm{N}_{\mathrm{i}}$ & $\begin{array}{l}\rho_{\mathrm{d}} \\
\left(10^{-5} \mathrm{~cm}^{-2}\right)\end{array}$ & $P\left(\chi^{2}\right)$ & $\begin{array}{l}\text { Central } \\
\text { Age } \\
(\mathrm{Ma})\end{array}$ & $\pm 1 \sigma$ & $\begin{array}{l}\text { Minimum } \\
\text { age (Ma) }\end{array}$ & $\pm 1 \sigma$ \\
\hline 10SJ10 & $30.0 \pm 1$ & 51 & $27.6-398.0$ & 73.2 & 2642 & 13.8 & 498 & 3.18 & 0 & 84.4 & 6.9 & 49.0 & 10.0 \\
\hline 09SJ33 & $31.5 \pm 1$ & 23 & $33.2-239.1$ & 86.9 & 2361 & 19.3 & 524 & 3.02 & 0 & 76.3 & 9.3 & 46.5 & 5.3 \\
\hline 09SJ29 & $33.0 \pm 1$ & 86 & $24.8-184.9$ & 95.0 & 8169 & 19.1 & 1641 & 3.04 & 0 & 74.0 & 4.0 & 43.7 & 4.3 \\
\hline
\end{tabular}

Note: Samples were counted dry with a BX51 Olympus microscope at $1250 \times$ magnification. Central and minimum ages were calculated with the RadialPlotter program of Vermeesch (2009), using a zeta value of $104.39 \pm 3.32$ and the CN1 dosimeter glass. 


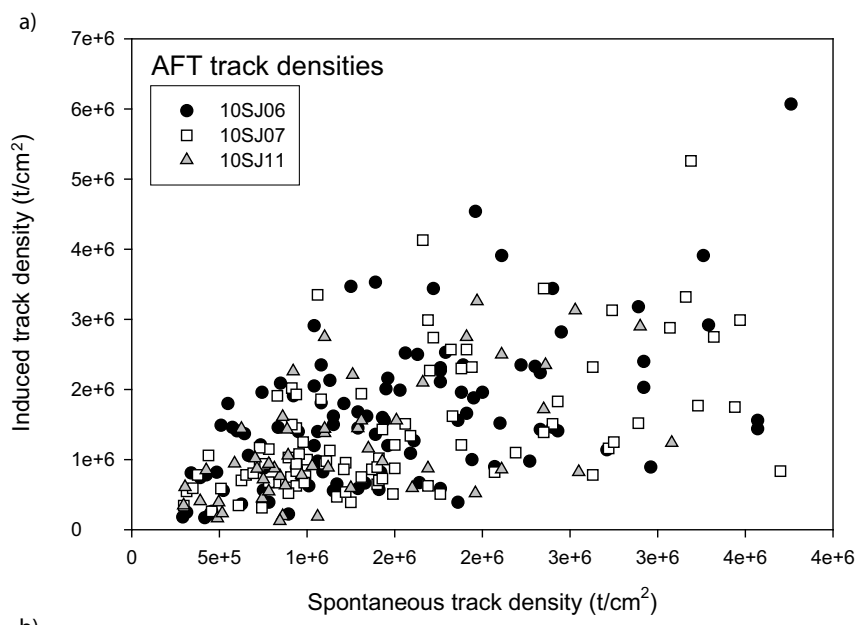

b)

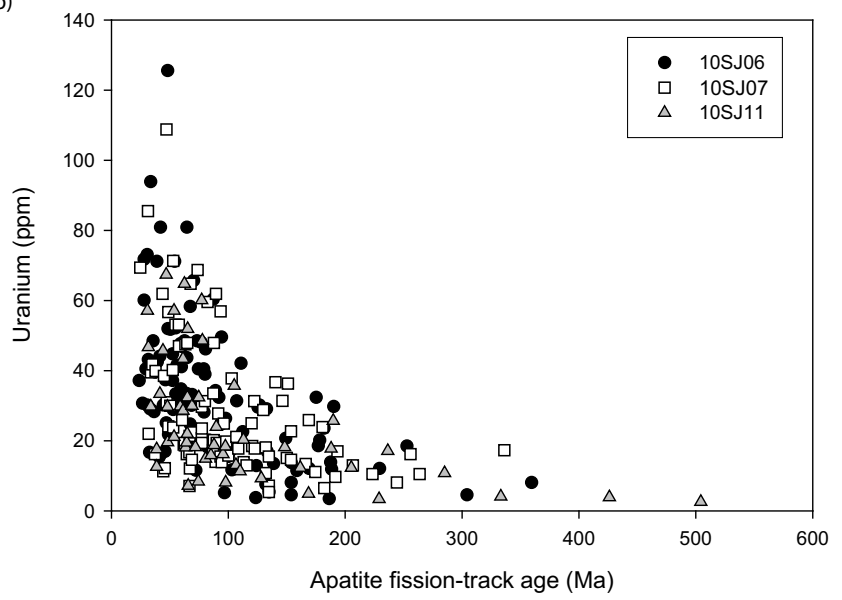

Fig 4. a) Spontaneous versus induced track density plot, and b) uranium concentration versus AFT age plot.

the grains show Hercynian ages $(\sim 360-280 \mathrm{Ma})$ and another $20-25 \%$ Pan African ages ( 460-660 Ma).

The zircon grain with a $30 \mathrm{Ma}$ U-Pb age also has a $34 \mathrm{Ma} \pm 25 \mathrm{ZFT}$ cooling age, which means that this grain has to be considered as the only Oligocene volcanic zircon grain observed in our samples. The ZFT data show that a few grains with Hercynian and Pan African crystallization ages have Eocene-Oligocene cooling ages, but otherwise show a large spread of apparent cooling ages between ca. 55-255 Ma (Fig. 8b).

\section{Discussion}

\subsection{Apatite and zircon fission-track ages in the source areas}

The grain age distribution of detrital apatite and zircon samples from sandstone reflects a mixture of apparent cooling ages in the drainage area at the time of deposition. The spread of the observed grain age distribution depends, among other factors, on the size of the drainage area, relief, erosion rates, bedrock lithologies, and of course the bedrock cooling history (e.g., Garver et al., 1999; Bernet et al., 2004). If fission-track data are available from the present-day outcrops in the drainage area, they can be compared with the detrital grain age distributions to provide valuable information and constraints on potential paleo-source areas. To the best of our knowledge, no bedrock ZFT data have been published for the MauresEsterel massif, but AFT ages between 21-37 Ma were determined for the Plan de la Tour granite, Moulin Blanc granite, and Bornes gneiss in the Maures massif; of about $93 \mathrm{Ma}$ for the Saint Tropez granite; and around 140 Ma in the Tanneron massif west of Cannes (Fig. 9; Lucazeau and Mailhé, 1986; Morillon, 1992, 1997; Jakni, 2000).

Paleozoic basement and Triassic-Jurassic cover rocks in eastern and western Sardinia have AFT ages over $50 \mathrm{Ma}$ and increase to 100 to $306 \mathrm{Ma}$ in southwestern Sardinia (Rossi et al., 2005; Zattin et al., 2008, Malusà et al., 2016). AFT cooling ages of $30 \mathrm{Ma}$ and younger can be found along the central graben in Sardinia, but the majority of AFT ages in Sardinia ranges from about 40 to $170 \mathrm{Ma}$ (Rossi et al., 2005; Malusà et al., 2016). ZFT ages throughout Sardinia are between 140-240 Ma (Fig. 9; Malusà et al., 2016). Single grain apatite (U-Th)/He data for Sardinia are as variable as the AFT ages, ranging from 26-204 Ma (Malusà et al., 2016).

A relatively dense AFT and ZFT dataset exists for Corsica (e.g., Cavazza et al., 2001; Zarki-Jakni et al., 2004; Fellin et al., 2005, 2006; Danisik et al., 2007). ZFT ages in Hercynian Corsica show an east-west trend from about $60-70 \mathrm{Ma}$ in the East, $110-180 \mathrm{Ma}$ in the central part, to $220-240 \mathrm{Ma}$ in the West (Fig. 9; also see summary in Danisik et al., 2007). Alpine Corsica ZFT ages are in general younger, ranging from about 110 to $20 \mathrm{Ma}$ (Fellin et al., 2006). AFT ages throughout Corsica are much more coherent at about 11-20 Ma and do not show the same regional pattern as the ZFT ages, with Alpine Corsica showing the youngest (Tertiary) AFT and ZFT ages (e.g., Cavazza et al., 2001; Zarki-Jakni et al., 2004).

Late Oligocene and Miocene AFT ages in the MauresEsterel massif, Sardinia and Corsica are related in the literature to extension during the phase of rifting in the ProvençalLigurian basin and counter-clockwise rotation of the CorsicaSardinia block away from the Maures-Esterel massif (Vigliotti and Langenheim, 1995; Séranne, 1999; Brunet et al., 2000; Rollet et al., 2002; Zarki-Jakni et al., 2004; Fellin et al., 2006; Danisik et al., 2007; Malusà et al., 2016). At the same time the Saint Antonin area experienced a phase of compression (Campredon and Giannerini, 1982), with gradual surface uplift and eventual exposure of the basin syncline. Late Triassic ZFT ages in western Corsica were interpreted to reflect partially annealed zircons during Jurassic rifting, and Early Jurassic to Late Cretaceous ZFT in central Corsica relate to the LiguriaPiedmont ocean opening according to Danisik et al. (2007) and Malusà et al. (2016). Nonetheless, the Late Cretaceous ZFT ages are debatable, as Fellin et al. (2006) considered such ZFT ages as well partial annealed ages.

\subsection{Provenance information from geo-thermochronological data}

Based on structural, paleomagnetic and petrographic data, Westphal et al. (1976) had already shown that the CorsicaSardinia block was directly connected with the Porvence area of southern France, with Corsica in a location close to where Nice and Cannes are today (Lacombe and Jolivet, 2005). In 
09SJ29 $(n=86)$

Central age $=74 \pm 4 \mathrm{Ma}(1 \sigma)$

Dispersion $=43 \%$

$\mathrm{P}\left(\chi^{2}\right)=0.00$
09SJ33 (n=23)

Central age $=76.3 \pm 9.3 \mathrm{Ma}(1 \sigma)$

Dispersion $=52 \%$

$P\left(\chi^{2}\right)=0.00$

Minimum age: $43.7 \pm 4.3 \mathrm{Ma}$
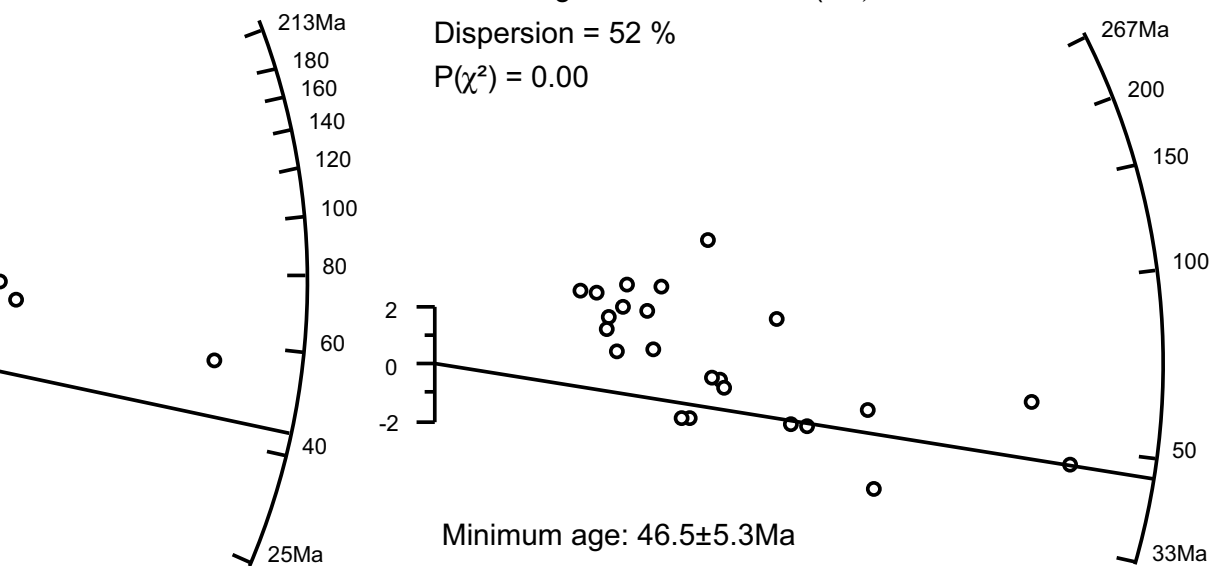
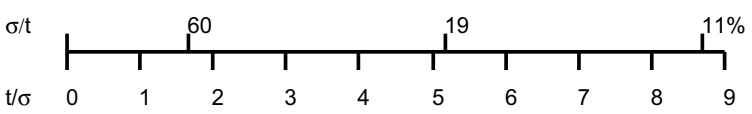

10SJ10 ( $n=51)$

Central age $=84.4 \pm 6.9 \mathrm{Ma}(1 \sigma)$

Dispersion $=47 \%$

$\mathrm{P}\left(\chi^{2}\right)=0.00$ $\sigma / \mathrm{t}$

$\mathrm{t} / \sigma$

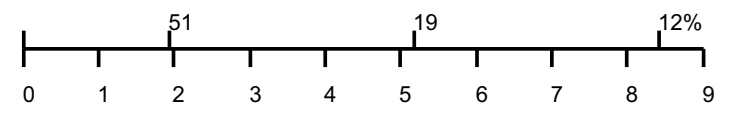

10SJ11 $(n=46)$

Central age $=74.6 \pm 7.5 \mathrm{Ma}(1 \sigma)$

Dispersion $=60 \%$

$\mathrm{P}\left(\chi^{2}\right)=0.00$
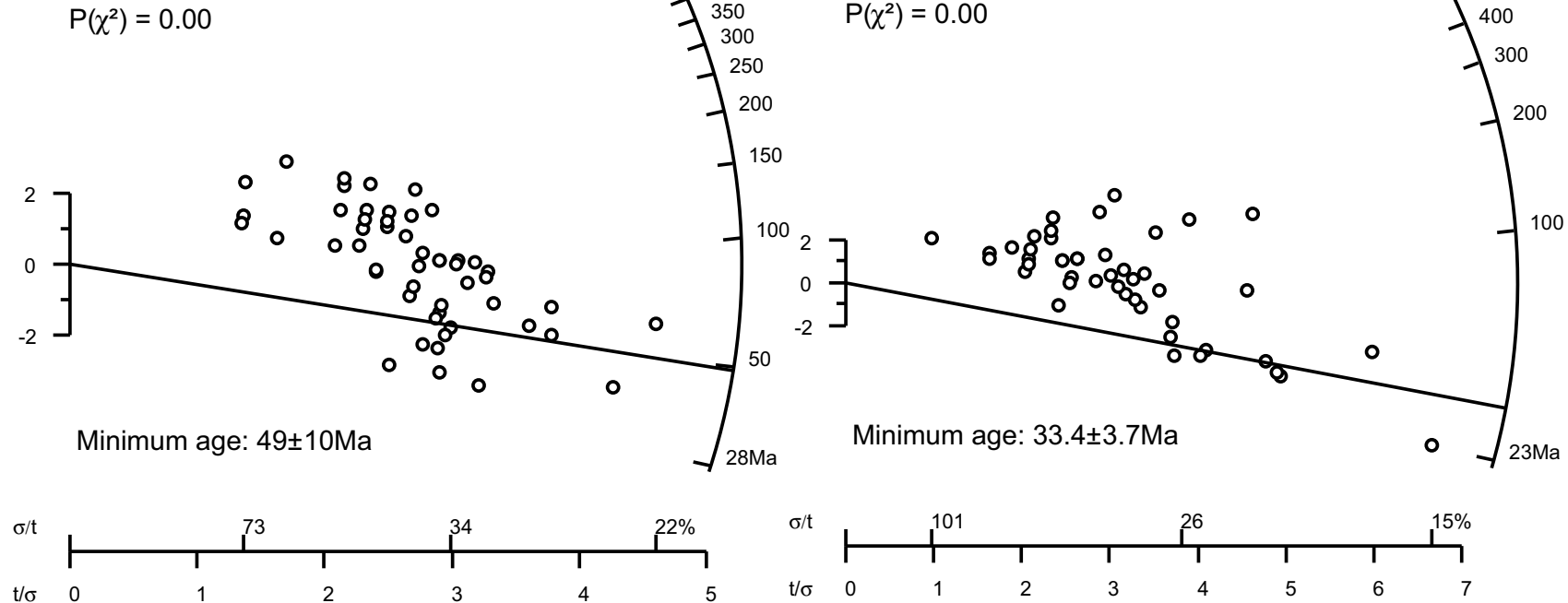

Fig. 5. Detrital ZFT age data shown in radial plots for sample 09SJ29 of Formation 1, sample 09SJ33 of Formation 2, and samples 10SJ10 and 10SJ11 of Formation 3. Graphs were plotted and central and minimum ages were calculated with the RadialPlotter program by Vermeesch (2009).

addition, from the sediment petrological and sedimentological evidence of the Saint Antonin basins mentioned above, the sediment source areas were located to the south and south-west of the basin, including the Maures-Esterel massif, Corsica and Sardina (Stanley, 1980; Campredon and Giannerini, 1982). The question is which of the three potential source areas is the most important? We first look at the zircon $\mathrm{U}-\mathrm{Pb}$ data to elaborate this question. Zircons with Pan-African and older U$\mathrm{Pb}$ ages are most likely derived from Permo-Triassic sedimentary cover rocks in the Maures-Esterel massif, Sardinia and Corsica, or from meta-sedimentary rocks of the Alpine Corsica zone. However, large fractions of zircons dated in this study have Hercynian U-Pb ages between 280 and $350 \mathrm{Ma}$. Hercynian granitic intrusions and migmatites are widespread throughout the Maures-Esterel massif, Sardinia and Corsica (e.g., Morillon et al., 2000; Duchesne et al., 2013). Therefore, the zircon $\mathrm{U}-\mathrm{Pb}$ data alone do not provide solid criteria for distinguishing between the three source areas. Only one zircon grain with an Oligocene crystallization age was identified, which is, given its corresponding ZFT cooling age, interpreted to be derived from a volcanic source. Because this contribution is very small, and because the andesite breccia we sampled in the Saint Antonin basin did not yield any apatite or zircon, we think that Oligocene volcanic rocks are not a major 

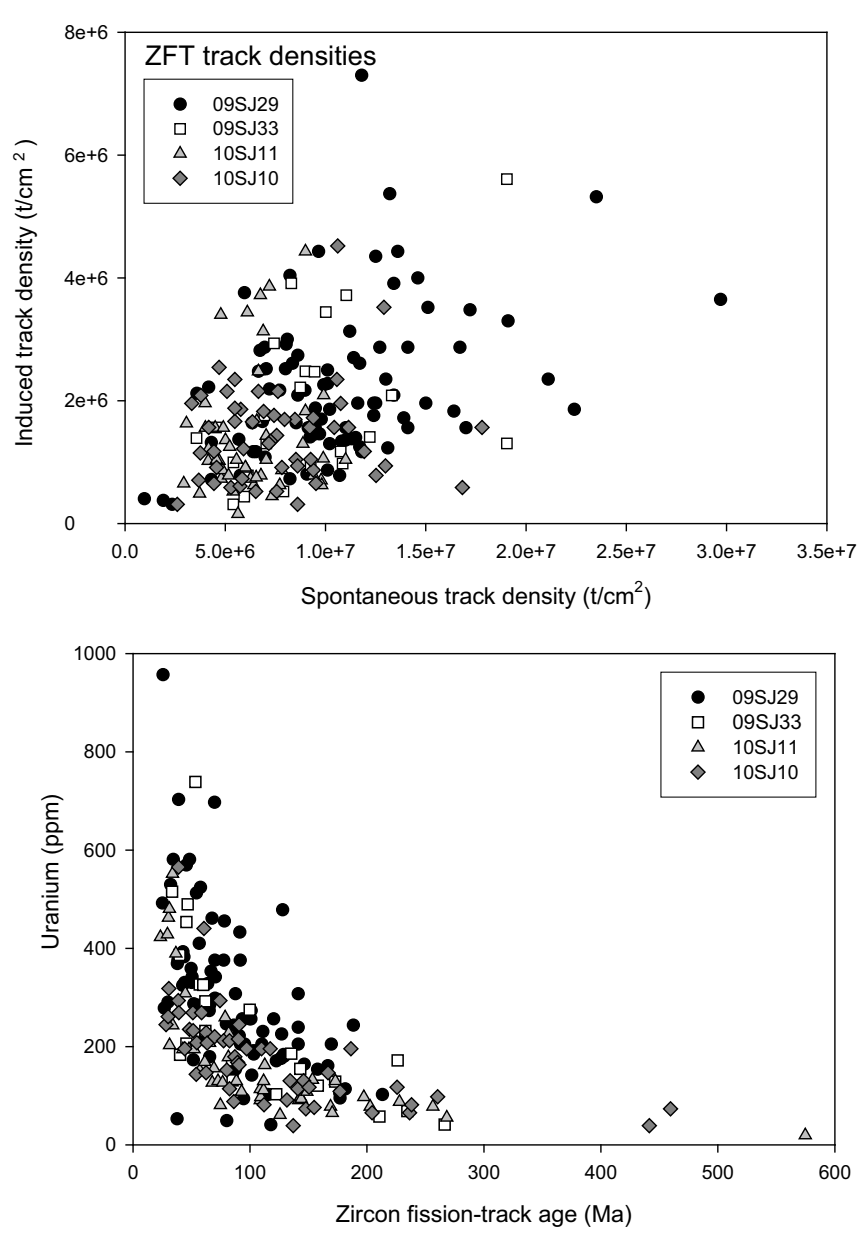

Fig. 6. a) Spontaneous versus induced track density plot, and b) Uranium concentration versus ZFT age plot.

source and the detrital AFT and ZFT cooling age signals discussed below represent source area exhumation. Here the questions is how can the AFT and ZFT ages be linked to source areas? A basic assumption is that for apatite and zircons with Eocene and early Oligocene cooling ages only bedrock exposed at the surface today which have early Oligocene or younger cooling ages can be considered as potential source areas (Fig. 9). In the Saint Antonin basin, we interpret apatites with early Oligocene cooling ages being mainly derived from source areas in Corsica and possibly from the Maures-Esterel massif, but there outcrops with early Oligocene AFT cooling ages are rather limited, at least from what is known from the published data (Fig. 12). Zircons with early Oligocene cooling ages have most likely a source area limited to Alpine Corsica, in the northeast of the island (Fig. 9). Alpine Corsica is separated from Hercynian Corsica by what is regarded as the southern extension of the Penninic front (Lacombe and Jolivet, 2005).

Apatites and zircons with Late Cretaceous to Early Tertiary apparent cooling ages may have been derived from very slowly cooled Hercynian intrusive rocks or from partially reset (cover?) units, which do not provide a clear age signal. Jurassic to Early Cretaceous apparent cooling ages most likely come from source rocks in the Maures-Esterel and Tanneron massifs, a)

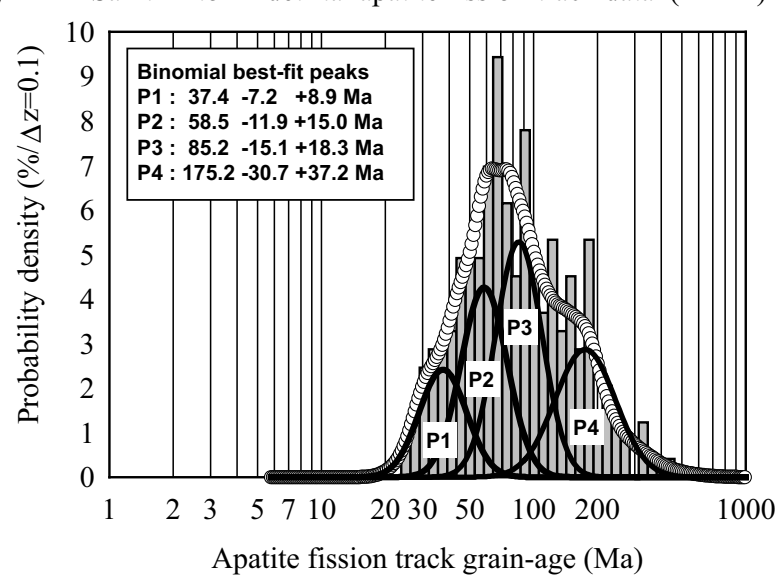

b)

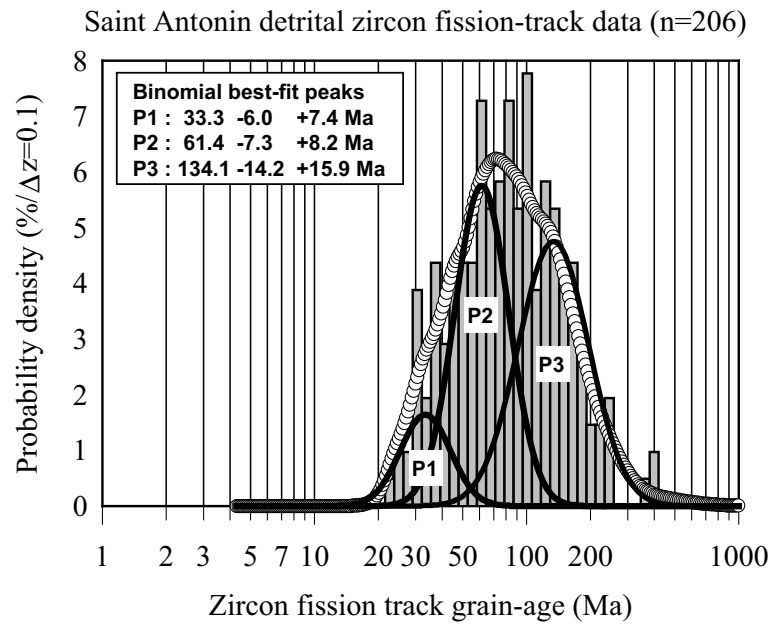

Fig. 7. a) and b) are respectively the observed grain-age distributions (dotted curves) and binomial best-fit peaks (black curves) of the combined AFT and ZFT data of the clastic Saint Antonin basin Formations 1 to 3 , determined with the BINOMFIT program of Brandon (see Ehlers et al., 2005).

Sardinia and Corsica (Fellin et al., 2006; Danisik et al., 2007; Malusà et al., 2016).

The zircon double-dating results in Figure $8 \mathrm{~b}$ show that these different sources need to be considered. The lack of a dense fission-track dataset in the Maures-Esterel massif prohibits more precise constraints. However, the published ZFT data from Corsica and Sardinia support potential source areas in the eastern, central and western parts of Hercynian Corsica for zircons with Early Cretaceous and older apparent fission-track cooling ages and Alpine Corsica for zircons with Late Cretaceous and Paleogene fission-track cooling ages (Fellin et al., 2006; Danisik et al., 2007; Malusà et al., 2016). We think that all of these Corsican sources were exposed and eroded during the early Oligocene and some of these sediments were deposited in the Saint Antonin basin, before Corsica and Sardinia drifted away during the late Oligocene-early Miocene (Lacombe and Jolivet (2005), and were removed as potential source areas, and the Saint Antonin basin was fully inverted and uplifted (Campredon and Giannerini, 1982). 
Table 4. Lag-time calculations. Bold means average values.

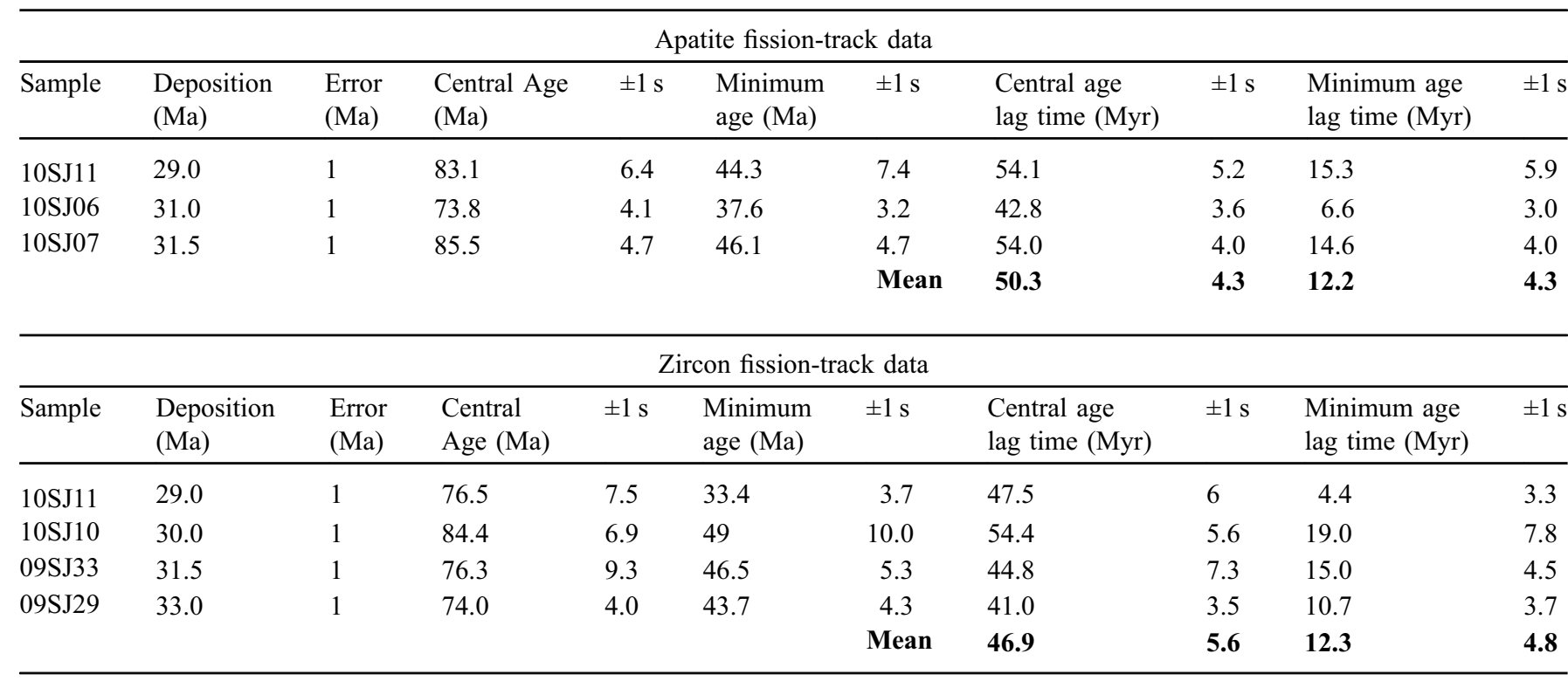

Data repository:

DR Table 1: Detrital zircon U-Pb data

DR Table 2: Detrital zircon fission-track/U-Pb double dating results

Zircon $\mathrm{U} / \mathrm{Pb}$ Concordia plots

Detailed apatite and zircon fission-track data

Given the overall younging age trend in the AFT and ZFT data that can be observed from southern Sardinia to northern Corsica suggests that northern Corsica was possibly the most prominent sediment source area for the Saint Antonin basin (Fig. 9; Malusà et al., 2016).

\subsection{Source area exhumation rates}

The minimum and central ages of the individual AFT and ZFT samples are clearly older than the given depositional ages between about 33 and $29 \mathrm{Ma}$. This, together with the relatively shallow burial of the sampled sedimentary rocks, suggests that fission-tracks in apatite and zircon were not affected by strong post-depositional annealing. As outlined above with the zircon double-dating results, a volcanic contribution seems to be negligible. Therefore, the AFT and ZFT data presented in this study can be used for estimating drainage basin average and maximum exhumation rates. The lag times shown in Table 4 can be used with Figure 11 to obtain first-order estimates of exhumation rates. Drainage basin average long-term exhumation rates determined from the mean central-age lag times are on the order of 0.1 to $0.2 \mathrm{~km} / \mathrm{Myr}$ (Fig. 10). The maximum exhumation rate estimates based on the minimum-age lag-time calculations are on the order of $0.4-0.7 \mathrm{~km} / \mathrm{Myr}$ (Fig. 10). Only about 10 to 15 percent of the dated apatite and zircon grains have Eocene to Oligocene cooling ages. While ignoring potential lithologic bias, this could mean that probably only small areas were affected by faster erosion. Overall slow erosion in the proximate source area of the Maures-Esterl massif is consistent white mica ${ }^{40} \mathrm{Ar} /{ }^{39} \mathrm{Ar}$ data from the Tanneron massif, which are in the 320-300 Ma range (Corsini et al., 2010), indicating that these rocks had cooled below temperatures of about $400-350{ }^{\circ} \mathrm{C}$ during the Carboniferous and where slowly exhumed afterwards, as no white micas with younger ${ }^{40} \mathrm{Ar} /{ }^{39} \mathrm{Ar}$ cooling ages were detected. Because the Pyrenees-Provence belt formed during the collision of the Corsican-Sardinia-Iberia block with the European plate during the Eocene (Arthaud and Séguret, 1981; Lacombe and Jolivet, 2005; Jolivet et al., 2015), the erosional response followed. Erosional exhumation was slow in the sources areas and may have accelerated only during the late Eocene-early Oligocene, when the erosional products were transported and deposited in the Saint Antonin basin, at the end of the PyreneoProvençal compression phase, and before late Oligocene-early Miocene Ligurian basin rifting had reached the region (Lacombe and Jolivet, 2005; Jolivet et al., 2015).

\subsection{Comparison with the Barrême basin}

If we compare detrital zircon U-Pb ages of the Saint Antonin basin with zircon $\mathrm{U}-\mathrm{Pb}$ ages from sandstone deposited between 30 and $29 \mathrm{Ma}$ in the Barrême basin, we see a similar age spread and a large number of zircons with Hercynian crystallization ages in both basins (Jourdan et al., 2013, and this study). However, using the Kolmogorov-Smirnov (KS) test (e.g., Press et al., 1992), we can determine if the difference between the zircon U-Pb age distributions for the two basins is significant or not. A $\mathrm{P}(\mathrm{KS})$ value of $<5 \%$ indicates that the difference is systematic and a $\mathrm{P}(\mathrm{KS})$ value of $>>5 \%$ indicates that the difference is most likely due to random chance alone. As shown in Figure 11a, with a $\mathrm{P}(\mathrm{KS})=0 \%$ the two distributions are significantly different in as much as many 


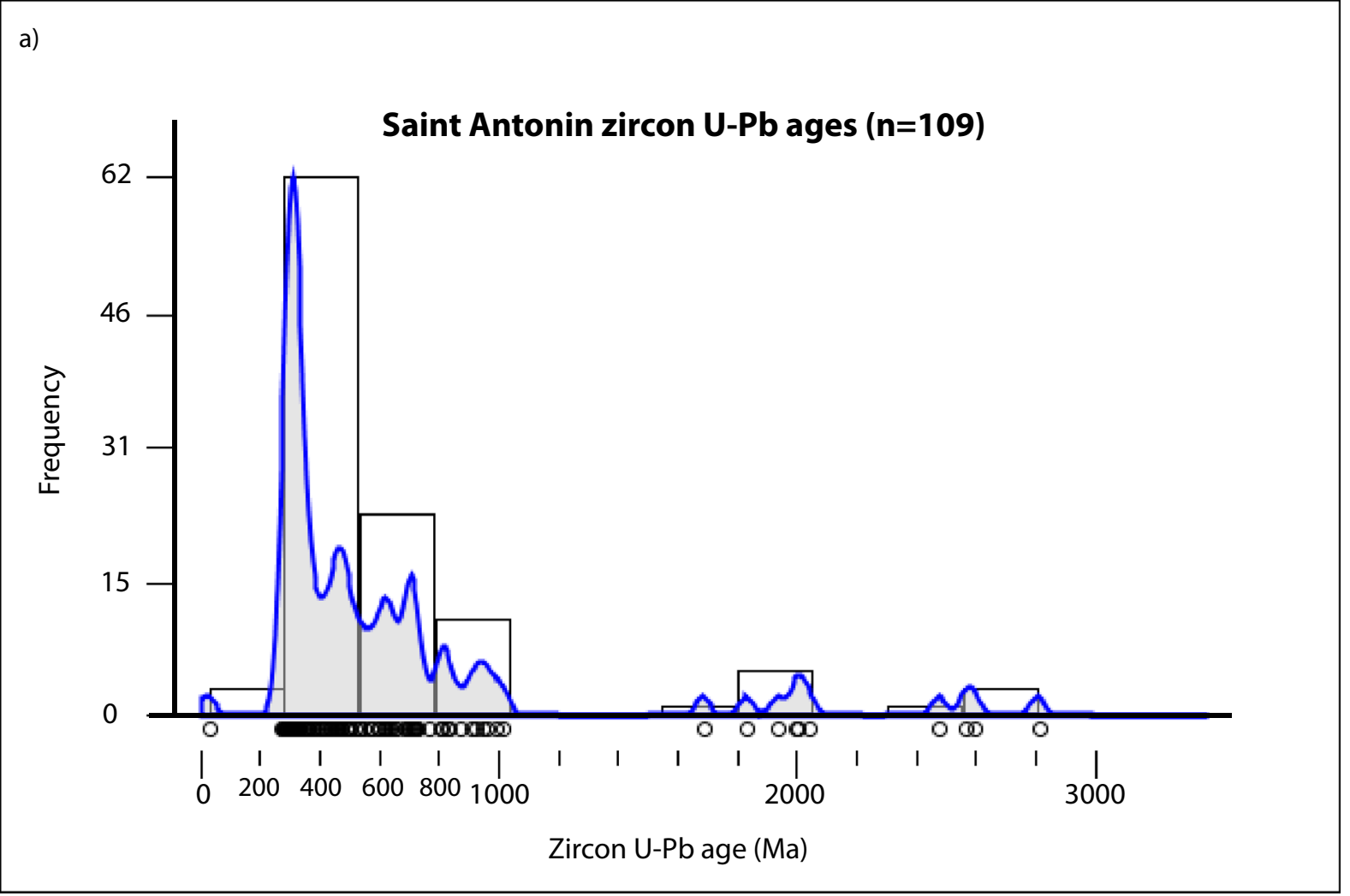

b)

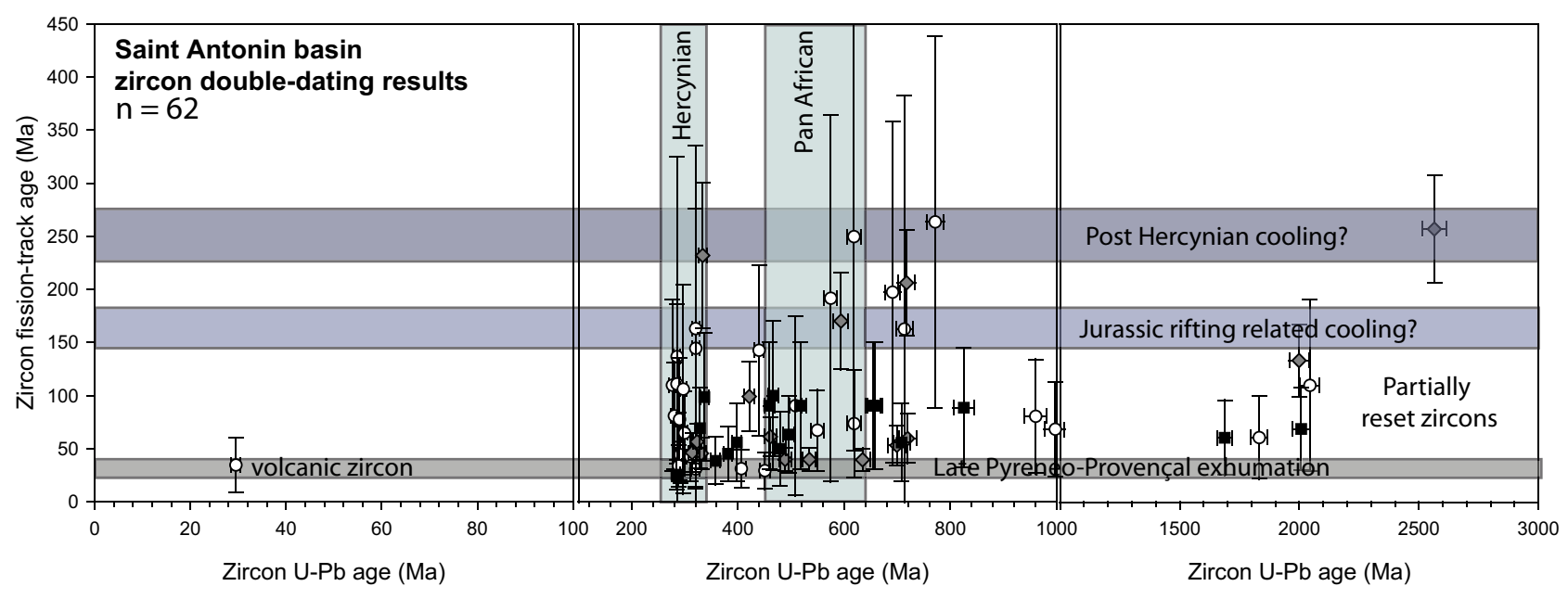

Fig 8. a) Combined data set of detrital zircon U-Pb ages from all three clastic formations of the Saint-Antonin basin. b) Double dating results of single grain detrital ZFT and U-Pb analyses.

more Oligocene volcanic zircons were identified in the Barrême basin deposits of the Clumanc and Saint Lions conglomerates (Jourdan et al., 2013) than in the Saint Antonin basin sedimentary rocks.

In the ZFT data, the differences are more striking, as the 30 to $29 \mathrm{Ma}$ Barrême basin deposits contain large numbers of zircons with $\sim 30 \mathrm{Ma}$ cooling ages (Fig. 11b). The $\mathrm{P}(\mathrm{KS})=0$ value emphasizes this significant difference. Jourdan et al. (2013) had shown with single zircon grain double-dating that only some of these grains are of volcanic origin, but the majority seems to reflect rapid source area exhumation in the Western Alps. Whereas zircons with 33 Ma fission-track cooling ages in the Saint Antonin basin make up only about $11 \%$ of the dated zircons, in the Clumanc and St. Lions conglomerates $\sim 30$ Ma zircons dominate, comprising 67-68\% of the dated grain-age distributions (Jourdan et al., 2013). In contrast, when comparing the ZFT grain-age distribution of the Grès de Ville, deposited between 31-30 Ma in the Barrême basin, with the ZFT grain-age distribution of the Saint Antonin basin, we see that the two distributions are very similar and a $\mathrm{P}$ 

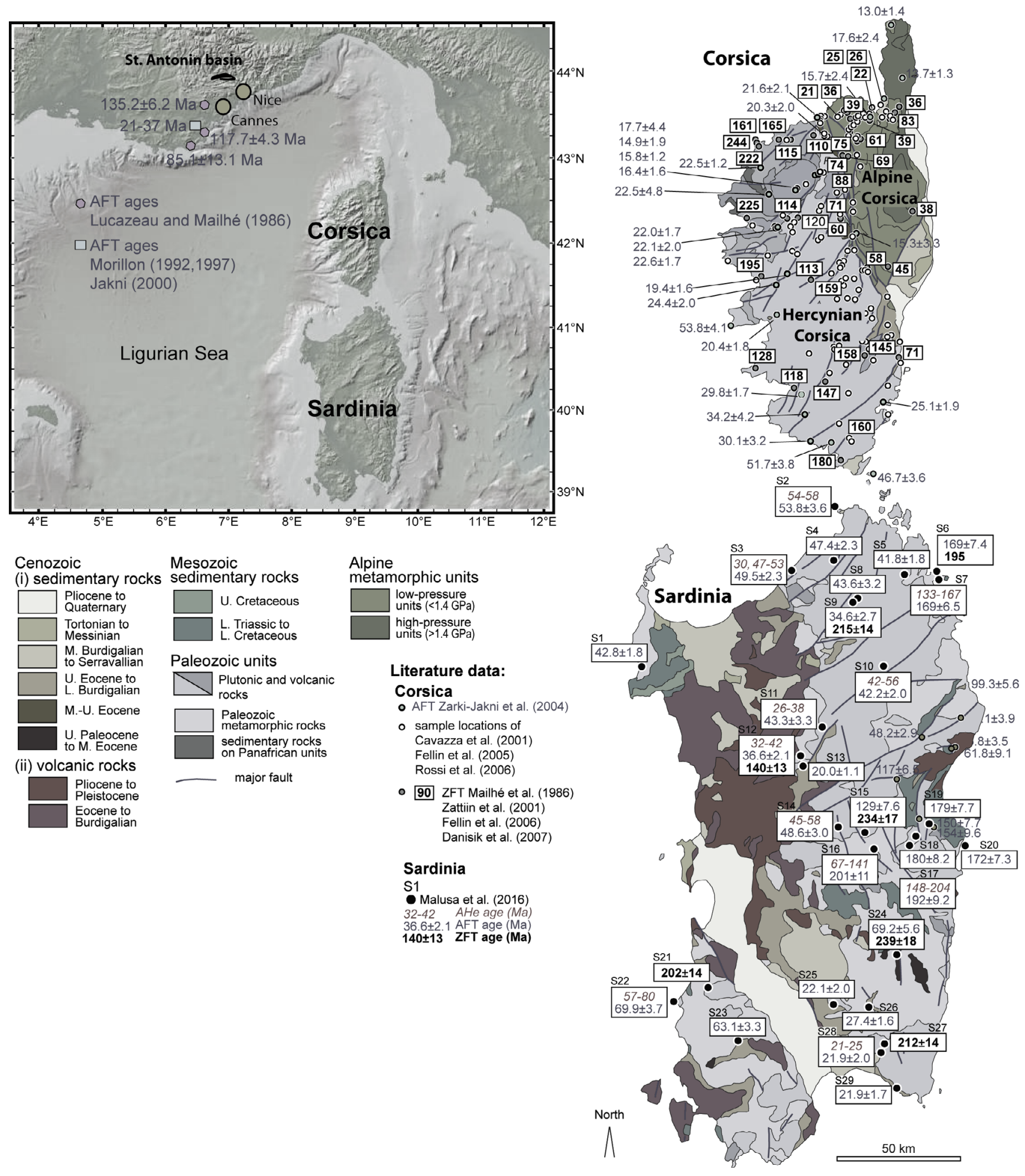

Fig. 9. Compilation of published bedrock apatite and zircon fission-track data of the Maures Esterel massif and the Corsica-Sardinia block. Data from Lucazeau and Mailhé (1986), Mailhé et al. (1986), Morillon (1992, 1997), Cavazza et al. (2001), Zarki-Jakni et al. (2004), Fellin et al. (2005, 2006), Rossi et al. (2005), Danisik et al. (2007), Zattin et al. (2008) and Malusà et al. (2016). Because of the large volume of data not all are shown, but the presented ages are representative. Overview map from GeoMapApp (http://www.geomapapp.org/). Corsica and Sardinia geological maps with sample locations were taken and modified from Malusà et al. (2016). 


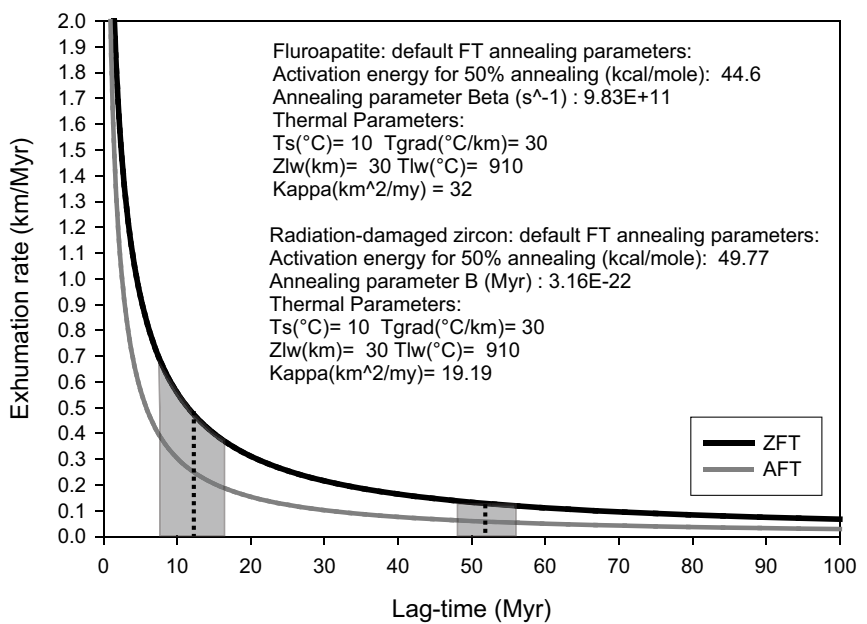

Fig. 10. First order estimates of source area exhumation rates from detrital apatite and zircon fission-track minimum-age and central-age lag times are derived from the 1-D steady-state thermal advection model age2edot by Brandon (see Ehlers et al., 2005 for details). Model parameters given in the plot are: Ts: surface temperature; Tgrad: thermal gradient; Zlw: crustal thickness; Tlw: temperature at the base of the crust; kappa: thermal diffusivity. The lag time (Myr) is the time difference between the age of deposition and the fission-track age. The black dotted lines show the mean lag-time estimates of the combined AFT and combined ZFT samples. The exhumation rate is estimated from the Y-axis.

$(\mathrm{KS})=31.1 \%$ value indicates that differences are most likely due to random chance alone (Fig. 11c). This result is not surprising as the Grès de Ville was sourced from the MauresEsterel massif to the south (Fig. 12; Evans and MangeRajetzky, 1991; Joseph and Lomas, 2004), similar to the Saint Antonin deposits and in contrast to the Clumanc and St. Lions conglomerates of the Barrême basin, which had their sources in the Western Alps (Evans and Mange-Rajetzky, 1991; Schwartz et al., 2012; Jourdan et al., 2013).

\subsection{Regional tectonics and basin evolution}

Formations 1, 2, and 3 of the Saint Antonin basin were deposited at roughly the same time as the Grès de Ville, Clumanc and Saint Lions conglomerates in the Barrême basin (Callec, 2001). Both basin remnants were affected by synsedimentary compressional deformation. The Barrême basin experienced east-west shortening, principally on its eastern flank between 30-28 Ma, when the first sediments arrived from the internal Western Alps (e.g., Evans and Mange-Rajetzky, 1991; Schwartz et al., 2012; Jourdan et al., 2013). The syn-sedimentary deformation in the Saint Antonin basin from the late Eocene to the early Oligocene was northsouth directed and mainly affected the southern flank of the basin. Therefore, the two basins show similar deformation styles but with different orientation of tectonic structures while being in the same Western Alps pro-side foreland basin stress field (Figs. 1, 9 and 12; e.g. Ford et al., 1999; Ford and Lickorish, 2004). The main phase of compressional tectonics in the Saint Antonin basin is linked to the final stages of the Pyreneo-Provençal N-S shortening phase, indicating that in this area compression occurred until about $28 \mathrm{Ma}$, during a)

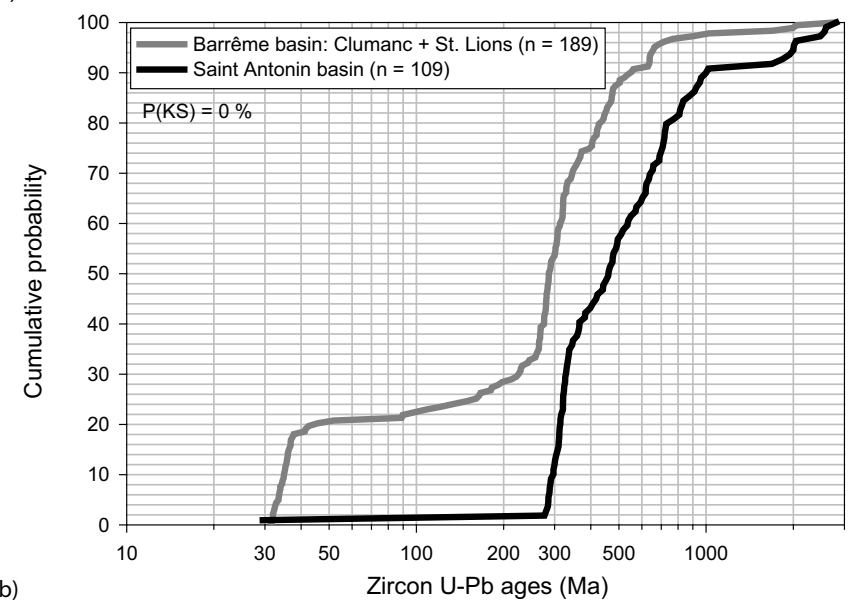

b)

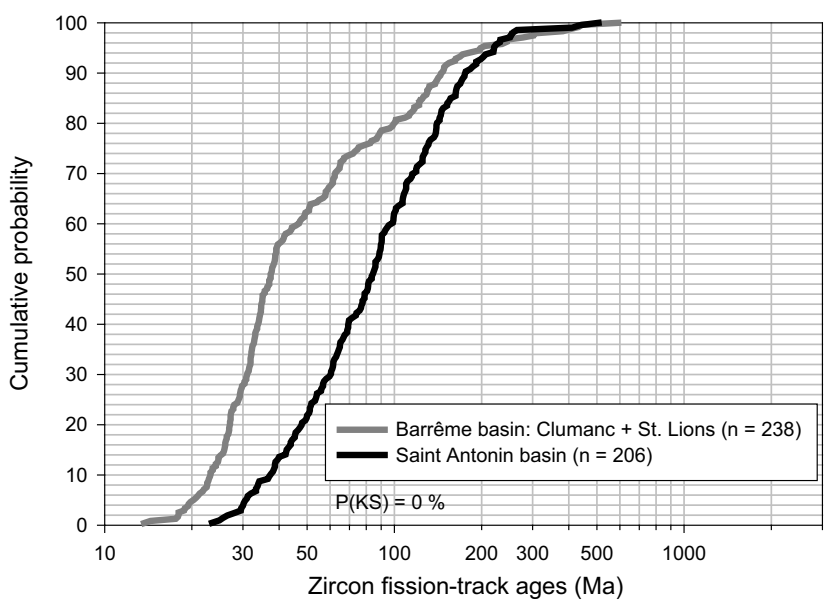

c)

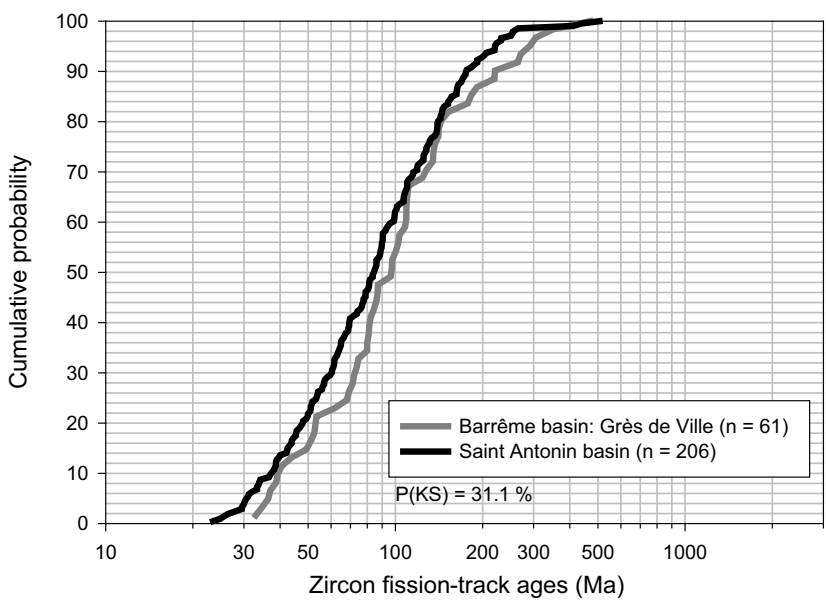

Fig. 11. a) Cumulative probability plots of the combined Saint Antonin zircon U-Pb data plotted against the combined zircon U-Pb data of the Clumanc and St. Lions conglomerates of the Barrême basin (Jourdan et al., 2013). A $\mathrm{P}(\mathrm{KS})=0 \%$ value shows that the two distributions are significantly different. b) Cumulative probability plots of the combined Saint Antonin ZFT data plotted against the combined ZFT data of the Clumanc and St. Lions conglomerates of the Barrême basin (Bernet et al., 2009; Jourdan et al., 2013). A $\mathrm{P}(\mathrm{KS})=0 \%$ value shows that the two distributions are significantly different, as is also the case with the zircon U-Pb ages. c) Cumulative probability plots of the combined Saint Antonin ZFT data plotted against the Grès de Ville ZFT data of the Barrême basin (Jourdan et al., 2013). A P(KS) $=31.1 \%$ value indicates that the two distributions are very similar and differences are probably only due to random chance variations. 

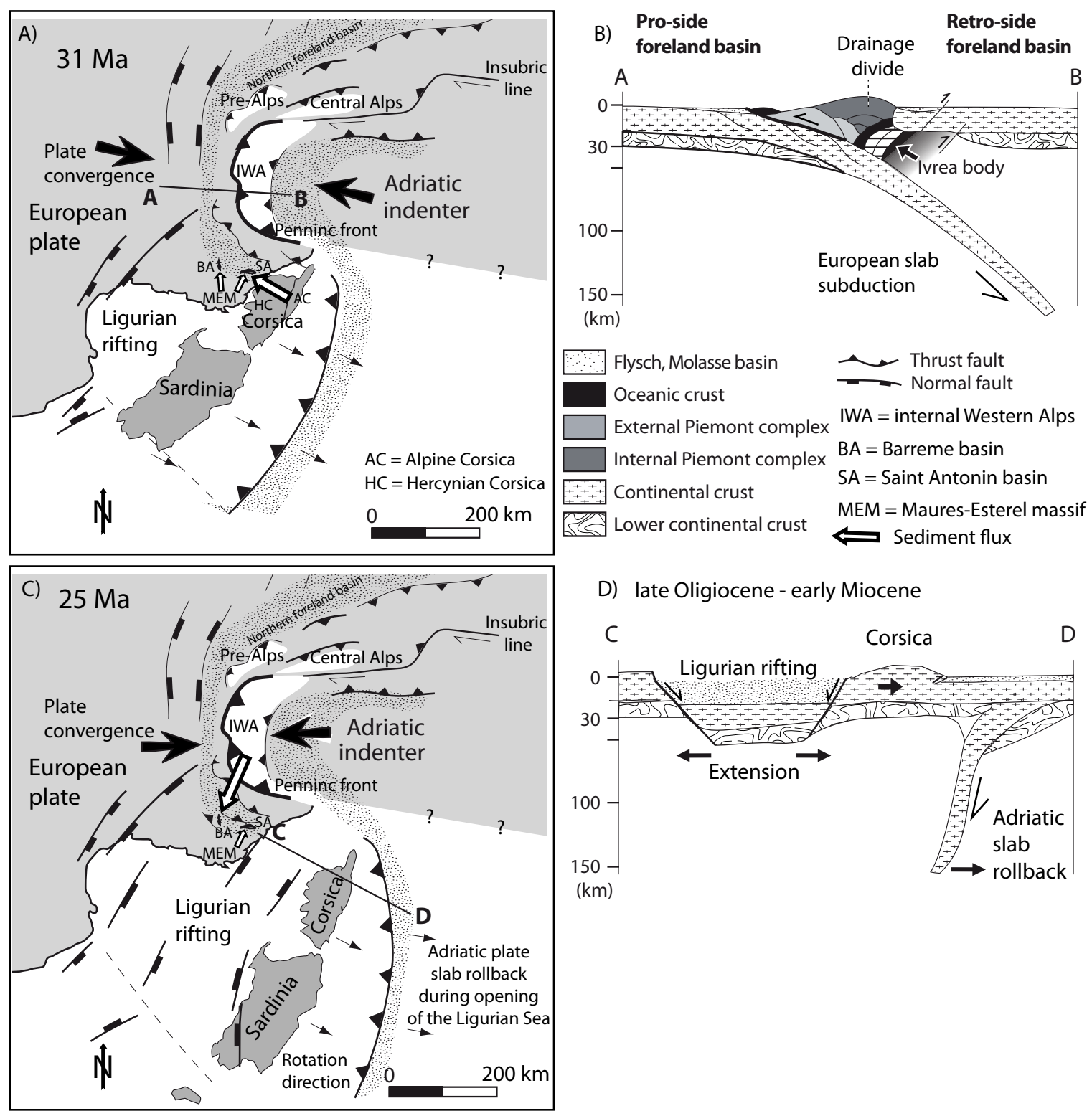

D) late Oligiocene - early Miocene

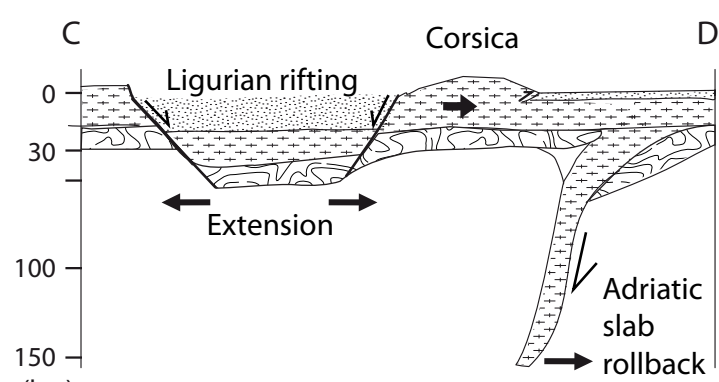

$(\mathrm{km})$

Fig. 12. Simplified paleogeographic model of the of the Western Alps south-eastern foreland basin with the Saint Antonin and Barrême basins at A-B) $31 \mathrm{Ma}$ and about $25 \mathrm{Ma} \mathrm{C}-\mathrm{D}$ ) with respect to the rising internal Western Alps, opening of the Ligurian Sea and rotation of the CorsicaSardinia block during the early to mid-Oligocene (modified after Lacombe and Jolivet, 2005; Dumont et al., 2012; Jourdan et al., 2013; and Malusà et al., 2015). White arrows indicated main sediment supply to the two basin remnants.

deposition of the 3rd clastic formation in the basin. This makes the Saint Antonin basin being a kind of foreland basin of the Pyreneo-Provençal thrust belt which includes the MauresEsterel massif, Corsica and Sardinia. Furthermore, the timing of deformation and rate of exhumation is comparable to what has been observed in the Pyrenees (e.g., Fitzgerald et al., 1999; Beamud et al., 2011; Vacherat et al., 2016).

From about $28 \mathrm{Ma}$ on rifting, which had already started in the Gulf de Lion region before, affected the region south of the Saint Antonin basin. This interpretation is consistent with the model proposed by Malusà et al. (2016) who based on AFT, ZFT and apatite (U-Th)/He data concluded that the late Oligocene and Miocene apparent cooling ages in Corsica are related to extensional cooling during rifting, but that northern Corsica experienced exhumational cooling caused of erosion during the late Eocene and early Oligocene times. As mentioned above, Alpine Corsica is separated from Hercynian Corsica by the southern extension of the Penninic front. Shortening along the Penninic front stopped here during the Oligocene (Lacombe and Jolivet, 2005), after the deposition of the Saint Antoni basin units, when the regional stress regime changed to extension during the opening of the Ligurian basin. This change coincides with the change in convergence between the Adriatic and European plate in the Western Alps as outlined by Dumont et al. (2012), and rollback of the Adriatic slab in the Mediterranean (e.g., Malusà et al., 2015). 
As mentioned above, only the Barrême basin recorded a significant change in sediment provenance from a southern to a north-eastern direction, whereas the Saint Antonin basin was sourced always only from the south (Fig. 12). The change in provenance in the Barrême basin and the east-west shorting has been explained with a change in convergence directions in the Western Alps between the Apulian and European plates during the mid-Oligocene (Fig. 12; e.g. Dumont et al., 2012). Whereas, the Barrême basin received molasse sedimentation until the early Miocene from the Western Alps (e.g., Evans and Mange-Rajetzky, 1991; Callec, 2001; Schwartz et al., 2012), and was continuously affected by east-west shortening, thrusting and transport on the Digne thrust-sheet (Fig. 12; e.g. Artoni and Meckel, 1998; Lickorish and Ford, 1998; Evans and Elliott, 1999; Evans et al., 2004), sedimentation stopped in the Saint Antonin basin and no late Oligocene to early Miocene molasse sediments were deposited, as Corsica, the most important sediment source area, was removed by the opening of the Ligurian basin. Therefore, regional tectonics were the main driver of basin subsidence, depositional environments, sediment provenance, syn-sedimentary deformation, and eventual basin inversion.

\section{Conclusions}

The geo-thermochronologic data of the Saint Antonin basin presented in this study are consistent with sediment provenance from the Maures-Esterel massif, Sardinia and Corsica. The Saint Antonin basin clastic formations were deposited between 33 and $28 \mathrm{Ma}$, at the end of the PyreneanProvencal collision phase and just before the initiation of the opening of the Ligurian Sea and rifting of Corsica and Sardinia away from the Maures-Esterel massif, and the single grain zircon fission-track and $\mathrm{U}-\mathrm{Pb}$ dating shows that a volcanic contribution is negligible, and apatites and zircons with early Oligocene fission-track cooling ages are in the Saint Antonin basin, even if rare, are regarded as the result of erosional exhumation at maximum rates of up to $0.4-0.7 \mathrm{~km} / \mathrm{Myr}$. The majority of the AFT and ZFT cooling ages however indicate overall relatively slow long-term average erosional exhumation rates on the order of $0.1-0.2 \mathrm{~km} / \mathrm{Myr}$ in the MauresEsterel, Sardinia and Corsica, consistent with the rather limited amount of sediments deposited in the Saint Antonin basin. In comparison, the published geo-thermochronologic data of the Barrême basin, show similar age ranges but with the difference of a large proportion of zircons with early Oligocene fissiontrack cooling ages, partly of volcanic origin and partly derived from rapid erosional exhumation in the Western Alps. The Saint Antonin basin deposits did not record a significant change in sediment provenance at about $30 \mathrm{Ma}$, as it has been documented in the Barrême basin. This means that the Saint Antonin basin was not affected by the same changes in foreland basin dynamics and sediment routing systems as the Barrême basin, even if the two foreland basin remnants are less than $50 \mathrm{~km}$ apart. In the Saint Antonin basin sedimentation ended around $28 \mathrm{Ma}$, with eventual basin inversion and surface uplift and removal of the main source areas in Corsica-Sardinia block by continued rifting in the Ligurian Sea.

Acknowledgements. This research was support by the ANRERD-Alps grant. We greatly appreciate the constructive and very helpful reviews of two anonymous reviewers and the associate editor. We also thank Massimilliano Zattin for comments on a previous version of this manuscript. The research was support by the ANR ERD-Alps project.

\section{References}

Andreani L, Loget N, Rangin C, Le Pichon X. 2010. New structural constraints on the southern Provence thrust belt (France): evidences for an Eocene shortening event linked to the Corsica-Sardinia subduction. Bull Soc geol Fr 181: 547-563.

Arthaud F, Séguret M. 1981. Les structures Pyrénéennes du Languedoc et du Golfe du Lion (Sud de la France). Bull Soc geol Fr 23: 51-63.

Artoni A, Meckel LD III. 1998. History and deformation rates of a thrust sheet top basin: the Barrême basin, western Alps, SE France. In: Mascle A, Puigdefabregas C, Luterbacher HP, Fernandez M, eds. Cenozoic Foreland Basins of Western Europe. Geological Society of London Special Publications 134: 213-237.

Beamud E, Muñoz JA, Fitzgerald PG, Baldwin SL, Garcés M, Cabrera L, et al. 2011. Magnetostratigraphy and detrital apatite fission track thermochronology in syntectonic conglomerates: Constraints on the exhumation of the south-central Pyrenees. Basin Res. DOI: 10.1111/j.1365-2117.2010.00492.x.

Beaudoin B, Campredon R, Franco M, Giannerini G, Gigot P, Grandjacquet C, et al. 1977. Âge de modalités de plissement des chaînes subalpines méridionales, $5^{\mathrm{e}}$ réunion annuelle des Sciences de la Terre, p. 49.

Bernet M, Garver JI. 2005. Fission-track analysis of detrital zircon. In: Reiners PW, Ehlers TA, eds. Low-temperature thermochronology: Techniques, interpretations, and applications. Reviews in Mineralogy and Geochemistry, Mineralogical Society of America 58: 205-238.

Bernet M, Brandon MT, Garver JI, Molitor BR. 2004. Fundamentals of detrital zircon fission-track analysis for provenance and exhumation studies with examples from the European Alps. Geological Society of America Special Papers 378: 25-36.

Bernet M, van der Beek P, Pik R, Huyghe P, Mugnier J.-L, Labrin E, et al. 2006. Miocene to Recent exhumation of the central Himalaya determined from combined detrital zircon fission-track and $\mathrm{U} / \mathrm{Pb}$ analysis of Siwalik sediments, western Nepal. Basin Research 18: 393-412.

Bernet M, Brandon M, Garver J, Balestieri ML, Ventura B, Zattin M. 2009. Exhuming the Alps through time: clues from detrital zircon fission-track thermochronology. Basin Research 21: 781-798.

Bodelle J. 1971. Les formations nummulitiques de l'arc de Castellane. Université de Nice, Ph.D. Thesis.

Brunet C, Monie P, Jolivet L, Cadet, JP. 2000. Migration of compression and extension in the Tyrrhenian Sea, insights from $\mathrm{Ar}$ 40/Ar-39 ages on micas along a transect from Corsica to Tuscany. Tectonophysics 321: 127-155.

Callec Y. 2001. La déformation synsédimentaire des bassins paléogènes de l'arc de Castellane (Annot, Barrême, St-Antonin). École des Mines de Paris, PhD Thesis p. 347.

Campredon R, Giannerini G. 1982. Le synclinal de Saint-Antonin (arc de Castellane, chaînes subalpines méridionales) Un exemple de bassin soumis à une déformation compressive permanente depuis l'Eocène supérieur. Géologie Alpine 58: 15-20.

Carter A. 1999. Present status and future avenues of source region discrimination and characterization using fission track analysis. Sedimentary Geology 124: 31-45. 
Carter A, Moss SJ. 1999. Combined detrital-zircon fission-track and $\mathrm{U}-\mathrm{Pb}$ dating: A new approach to understanding hinterland evolution. Geology 27: 253-238.

Cavazza W, Zattin M, Ventura B, Zuffa GG. 2001. Apatite fissiontrack analysis of Neogene exhumation in northern Corsica (France). Terra Nova 13: 51-57.

Cerveny PF, Naeser ND, Zeitler PK, Naeser CW, Johnson NM. 1988. History of uplift and relief of the Himalaya during the past 18 million years: Evidence from fission-track ages of detrital zircons from sandstones of the Siwalik Group. In: Kleinspehn K, Paola C, eds. New perspectives in basin analysis. New York: SpringerVerlag, pp. 43-61.

Corsini M, Bosse V, Féraud G, Demoux A, Cervola G. 2010. Exhumation processes during post-collisional stage in the Variscan belt revealed by detailed 40Ar/39Ar study (Tanneron Massif, SE France). International Journal of Earth Sciences 99: 327-341.

Danisik M, Kuhlemann J, Dunkl I, Szekeley B, Frisch W. 2007. Burial and exhumation of Corsica (France) in the light of fission track data. Tectonics. DOI: 10.1029/2005tc001938.

Duchesne JC, Liégois JP, Bolle O, Vander Auwera J, Bruguier O, Matukov DI, et al. 2013. The fast evolution of a crustal hot zone at the end of a transpressional regime: The Saint-Tropez peninsula granites and related dykes (Maures Massif, SE France). Lithos 162-162: 195-220.

Dumont T, Schwartz S, Guillot S, Simon-Labric T, Tricart P, Jourdan S. 2012. Structural and sedimentary records of the Oligocene revolution in the Western Alpine arc. Journal of Geodynamics 5657: $18-38$.

Ehlers TA, Chaudhri T, Kumar S, Fuller CW, Willett SD, Ketcham RA, et al. 2005. Computational tools for low-temperature thermochronometer interpretation. In: Reiners PW, Ehlers TA, eds. Low-temperature thermochronology: Techniques, interpretations, and applications. Reviews in Mineralogy and Geochemistry, Mineralogical Society of America 58: 589-622.

Evans MJ, Mange-Rajetzky MA. 1991. The provenance of sediments in the Barrême thrust-top basin, Haute-Provence, France, Developments in Sedimentary Provenance Studies. Geological Society of London Special Publications 57: 323-342.

Evans MJ, Elliott T. 1999. Evolution of a thrust-sheet-top basin: The Tertiary Barrême basin, Alpes-de-Haute-Provence, France. Geological Society of America Bulletin 111: 1617-1643.

Evans MJ, Elliott T, Apps GM, Mange-Rajetzky MA. 2004. The Tertiary Gres de Ville of the Barrême Basin: feather edge equivalent to the Gres d'Annot? In: Joseph P, Lomas SA, eds. Deep-Water Sedimentation in the Alpine Basin of SE France: New Perspectives on the Grès D'Annot and related systems. Geological Society of London Special Publications 221: 97-110.

Fellin MG, Zattin M, Picotti V, Reiners PW, Nicolescu S. 2005. Relief evolution in northern Corsica (western Mediterranean): Constraints on uplift and erosion on long-term and short-term timescales. Journal of Geophysical Research-Earth Surface 110. DOI: 10.1029/2004jf000167.

Fellin MG, Vance JA, Garver JI, Zattin M. 2006. The thermal evolution of Corsica as recorded by zircon fission-tracks. Tectonophysics 421: 299-317.

Fitzgerald PG, Muñoz JA, Coney PJ, Baldwin SL. 1999. Asymmetric exhumation across the Pyrenean orogen: Implications for the tectonic evolution of a collisional orogen. Earth Planet. Sci Lett 173: $157-170$.

Ford M, Lickorish WH. 2004. Foreland basin evolution around the western Alpine Arc. In: Joseph P, Lomas SA, eds. Deep-Water Sedimentation in the Alpine Basin of Se France: New perspectives on the Grès d'Annot and related systems. Geological Society of London Special Publications 221: 39-63.

Ford M, Lickorish WH, Kusznir NJ. 1999. Tertiary foreland sedimentation in the Southern Subalpine Chains, SE France: a geodynamic appraisal. Basin Research 11: 315-336.

Fournier M, Jolivet L, Goffe B, Dubois R. 1991. Alpine Corsica metamorphic core complex. Tectonics 10: 1173-1186.

Galbraith RF, Laslett GM. 1993. Statistical models for mixed fissiontrack ages. Nuclear Tracks Radiation Measurements 21: 459-470.

Garver JI, Brandon MT, Roden-Tice M, Kamp PJJ. 1999. Exhumation history of orogenic highlands determined by detrital fission-track thermochronology. In: Ring U, Brandon MT, Lister GS, Willett SD, eds. Exhumation Processes: Normal Faulting, Ductile Flow and Erosion. Geological Society of London Special Publications 154: 283-304.

Hurai V, Paquette JL, Huraiová M, Konečný P. 2010. Age of deep crustal magmatic chambers in the intra-Carpathian back-arc basin inferred from LA-ICPMS U-Th-Pb dating of zircon and monazite from igneous xenoliths in alkali basalts. Journal of Volcanology and Geothermal Research 198: 275-287.

Hurai V, Paquette JL, Huraiová M, Sabol M. 2012. U-Pb geochronology of zircons from fossiliferous sediments 1 of the Hajnáčka I maar (Slovakia)-type locality of the MN16a biostratigraphic subzone. Geological Magazine 149: 989-1000.

Jakni B. 2000. Thermochronologie par Trace de Fission des marges conjuguées du bassin liguro-provençal : la Corse et le massif des Maures-Tanneron. Université de Grenoble, PhD Thesis p. 346.

Jolivet L, Dubois R, Fournier M, Goffe B, Michard A, Jourdan C. 1990. Ductile extention in Alpine Corsica. Geology 18: 1007 1010.

Jolivet L, Daniel JM, Fournier M. 1991. Geometry and kinematics of ductile extension in Alpine Corsica. Earth Planet Sci Lett 104: 278-291.

Jolivet L, Gorini C, Smit J, Leroy S. 2015. Continental breakup and the dynamics of rifting in back-arc basins: The Gulf of Lion margin. Tectonics 34: 662-679.

Joseph P, Lomas SA. 2004. Deep-water sedimentation in the Alpine Foreland Basin of SE France. In: Joseph P, Lomas SA, eds. DeepWater Sedimentation in the Alpine Basin of SE France: New Perspectives on the Grès D'Annot and related systems. Geological Society of London Special Publications 221: 1-16.

Jourdan S, Bernet M, Tricart P, Hardwick E, Paquette JL, Guillot S, et al. 2013. Short-lived, fast erosional exhumation of the internal Western Alps during the late early Oligocene; constraints from geothermochronology of pro- and retro-side foreland basin sediments. Lithosphere 5: 211-225.

Lacombe O, Jolivet L 2005. Structural and kinematic relationships between Corsica and the Pyrenees-Provence domain at the time of the Pyrenean orogeny. Tectonics 24: TC1003. DOI: 10.1029/ 2004 TC001673.

Lickorish WH, Ford M. 1998. Sequential restoration of the external Alpine Digne thrust system, SE France, constrained by kinematic data and synorogenic sediments. In: Mascle A, Puigdefabregas C, Lutebacher HP, Fernandez M, eds. Cenozoic Foreland Basins of Western Europe. Geological Society of London Special Publications 134: 189-211.

Lucazeau F, Mailhé D. 1986. Heat flow, heat production and fissiontrack data from the Hercynian Basement around the Provençal basin (western Mediterranean). Tectononophysics 128: 335-356.

Mailhé D, Lucazeau, F, Vasseur G. 1986. Uplift history of thrust belts: An approach based on fission-track data and thermal modelization. Tectonophysics 124: 177-191. 
Malavieille J, Chemenda A, Larroque C. 1998. Evolutionary model for Alpine Corsica: mechanism for ophiolite emplacement and exhumation of high-pressure rocks. Terra Nova 10: 317-322.

Malusà MG, Faccenna C, Baldwin SL, Fitzgerald PG, Rossetti F, Balestrieri ML, et al. 2015. Contrasting styles of (U)HP rock exhumation along the Cenozoic Adria-Europe plate boundary (Western Alps, Calabria, Corsica). Geochem Geophys Geosyst 16: $1786-1824$.

Malusà MG, Danisik M, Kuhlemann J. 2016. Tracking the Adriatic-slab travel beneath the Tethyan margin of Corsica-Sardinia by lowtemperature thermochronometry. Gondwana Research 31: 135-149.

Montenat C, Leyrit H, Gillot P-Y., Janin M-C., Barrier P. 1999. Extention du volanisme oligocène dans l'arc de Castellane (chaînes subalpines de Haute-Provence). Géologie de la France 1: 43-48.

Morillon AC. 1992. Refroidissement et cinématique d'un pluton tardi-orogenique : le granite de Plan de la Tour (Massif des Maures, Var, France). Mémoire du D.E.A., Sophia Antipolis.

Morillon AC. 1997. Étude thermo-chronométrique appliquée aux exhumations et contexte orogénique: le Massif des Maures (France) et Les Cordillères Bétiques (Espagne). PhD Thesis, Nice, $289 \mathrm{p}$.

Morillon AC, Feraud G, Sosson M, Ruffet G, Crevola G, Lerouge G. 2000. Diachronous cooling on both sides of a major strike slip fault in the Variscan Maures Massif (south-east France), as deduced from a detailed Ar-40/Ar-39 study. Tectonophysics 321: 103-126.

Press WH, Teukolsky SA, Vetterling WT, Flannery BP. 1992. Numerical recipes in FORTRAN. New York: Cambridge University Press, p. 609.

Rollet N, Déverchère J, Beslier M-O, Guennoc P, Réhault J-P, Sosson M, Truffert C. 2002. Back arc extension, tectonic inheritance, and volcanism in the Ligurian Sea, Western Mediterranean. Tectonics 21. DOI: 10.1029/2001TC900027.

Rosenbaum G, Lister GS, Duboz C. 2002. Reconstruction of the tectonic evolution of the western Mediterranean since the Oligocene. Journal of the Virtual Explorer 8: 107-130.

Rossi P, Bigot-Cormier F, Saddiqi O, Poupeau G, Sosson M. 2005. Exhumation of Sardinia: apatite fission-track results. Geophysical Research Abstracts 7: 10073. Sref-ID: 1607-7962/gra/EGU05-A10073.

Schreiber D, Lardeaux JM, Martelet G, Courrioux G, Guillen A. 2010. 3-D modelling of Alpine Mohos in Southwestern Alps. Geophysical Journal International 180: 961-975.

Schwartz S, Guillot S, Tricart P, Bernet M, Jourdan S, Dumont T, Montagnac G. 2012. Source tracing of detrital serpentinite in the Oligocene molasse deposits from the western Alps (Barrême basin): implications for relief formation in the internal zone. Geological Magazine 149: 841-856.

Séranne M. 1999. The Gulf of Lion continental margin (NW Mediterranean) revisited by IBS: an overview. Geological Society of London Special Publications 156: 15-36.

Stanley DJ. 1964. Heavy mineral and provenance of sand in flysch of central and southern French alps. Bulletin of the American Association of Petroleum Geologist 49: 22-40.

Stanley DJ. 1980. The Saint-Antonin Conglomerate in the Maritime Alps: A model for coarse sedimentation on a submarine slope. Smithsonian contributions to the marine sciences 5. City of Washington: Smithsonian Intsitution Press, $28 \mathrm{p}$.

Stewart RJ, Brandon MT. 2004. Detrital-zircon fission-track ages for the "Hoh Formation": Implications for late Cenozoic evolution of the Cascadia subduction wedge. Geological Society of America Bulletin 116: 60-75.

Toure S. 1981. Données nouvelles sur les formations détritiques de l'arc de Castelanne, Sud-Est de la France (conglomérats tertiaires des synclinaux de Saint-Antonin, Barrême, Majastre). Pétrologie des galets de roches endogenes. Application de la typologie du zircon accessoire. Approche paléogéographique. Université de Nice, $\mathrm{PhD}$ Thesis.

Vacherat A, Mouthereau F, Pik R, Bellahsen N, Gautheron C, Bernet $\mathrm{M}$, et al. 2016. Rift-to-collision transition recorded by tectonothermal evolution of the northern Pyrenees. Tectonics 35: 907-933.

Vermeesch P. 2009. RadialPlotter: A Java application for fission track, luminescence and other radial plots. Radiation Measurement 44: 409-410.

Vigliotti L, Langenheim VE. 1995. When did Sardinia stop rotating - new paleomegnetic results. Terra Nova 7: 424-435.

Westphal M, Orsini J, Vellutini J. 1976. Le microcontinent corsosarde, sa position initiale: données paléomagnétiques et raccords géologiques. Tectonophysics 30: 141-157.

Zarki-Jakni B, van der Beek P, Poupeau G, Sosson M, Labrin E, Rossi $\mathrm{P}$, et al. 2004. Cenozoic denudation of Corsica in response to Ligurian and Tyrrhenian extension: Results from apatite fission track thermochronology. Tectonics 23. DOI: 10.1029/ 2003 tc001535.

Zattin M, Massari F, Dieni I. 2008 Thermochronological evidence for Mesozoic-Tertiary tectonic evolution in the eastern Sardinia. Terra Nova 20: 469-474.

Zeitler PK, Johnson NM, Briggs ND, Naeser CW. 1986. Uplift history of the NW Himalaya as recorded by fission-track ages on detrital Siwalik zircons. Proceedings of the Symposium on Mesozoic and Cenozoic Geology, China, pp. 481-494.

Cite this article as: Jourdan S, Bernet M, Hardwick E, Paquette J-L, Tricart P, Senebier F, Coeur F. 2018. Geo-thermochronology of the Saint Antonin basin, south-eastern France, BSGF - Earth Sciences Bulletin 189: 12. 